\title{
Inorganic carbon dynamics of melt-pond-covered first-year sea ice in the Canadian Arctic
}

\author{
N.-X. Geilfus ${ }^{1,2}$, R. J. Galley ${ }^{1}$, O. Crabeck ${ }^{1}$, T. Papakyriakou ${ }^{1}$, J. Landy ${ }^{1}$, J.-L. Tison ${ }^{3}$, and S. Rysgaard ${ }^{1,2,4}$ \\ ${ }^{1}$ Centre for Earth Observation Science, Department of Environment and Geography, University of Manitoba, \\ Winnipeg, Canada \\ ${ }^{2}$ Arctic Research Centre, Aarhus University, Aarhus, Denmark \\ ${ }^{3}$ Laboratoire de Glaciologie, DSTE, Université Libre de Bruxelles, Brussels, Belgium \\ ${ }^{4}$ Greenland Climate Research Centre, Greenland Institute of Natural Resources, Nuuk, Greenland
}

Correspondence to: N.-X. Geilfus (geilfus@bios.au.dk)

Received: 26 March 2014 - Published in Biogeosciences Discuss.: 23 May 2014

Revised: 22 January 2015 - Accepted: 13 March 2015 - Published: 31 March 2015

\begin{abstract}
Melt pond formation is a common feature of spring and summer Arctic sea ice, but the role and impact of sea ice melt and pond formation on both the direction and size of $\mathrm{CO}_{2}$ fluxes between air and sea is still unknown. Here we report on the $\mathrm{CO}_{2}$-carbonate chemistry of melting sea ice, melt ponds and the underlying seawater as well as $\mathrm{CO}_{2}$ fluxes at the surface of first-year landfast sea ice in the Resolute Passage, Nunavut, in June 2012.

Early in the melt season, the increase in ice temperature and the subsequent decrease in bulk ice salinity promote a strong decrease of the total alkalinity (TA), total dissolved inorganic carbon $\left(T \mathrm{CO}_{2}\right)$ and partial pressure of $\mathrm{CO}_{2}\left(p \mathrm{CO}_{2}\right)$ within the bulk sea ice and the brine. As sea ice melt progresses, melt ponds form, mainly from melted snow, leading to a low in situ melt pond $p \mathrm{CO}_{2}(36 \mu \mathrm{atm})$. The percolation of this low salinity and low $p \mathrm{CO}_{2}$ meltwater into the sea ice matrix decreased the brine salinity, TA and $T \mathrm{CO}_{2}$, and lowered the in situ brine $p \mathrm{CO}_{2}$ (to $20 \mu \mathrm{atm}$ ). This initial low in situ $p \mathrm{CO}_{2}$ observed in brine and melt ponds results in air-ice $\mathrm{CO}_{2}$ fluxes ranging between -0.04 and $-5.4 \mathrm{mmol} \mathrm{m}^{-2} \mathrm{day}^{-1}$ (negative sign for fluxes from the atmosphere into the ocean). As melt ponds strive to reach $p \mathrm{CO}_{2}$ equilibrium with the atmosphere, their in situ $p \mathrm{CO}_{2}$ increases (up to $380 \mu \mathrm{atm}$ ) with time and the percolation of this relatively high concentration $p \mathrm{CO}_{2}$ meltwater increases the in situ brine $p \mathrm{CO}_{2}$ within the sea ice matrix as the melt season progresses. As the melt pond $p \mathrm{CO}_{2}$ increases, the uptake of atmospheric $\mathrm{CO}_{2}$ becomes less significant. However, since melt ponds are continuously supplied by meltwa-
\end{abstract}

ter, their in situ $p \mathrm{CO}_{2}$ remains undersaturated with respect to the atmosphere, promoting a continuous but moderate uptake of $\mathrm{CO}_{2}\left(\sim-1 \mathrm{mmolm}^{-2} \mathrm{day}^{-1}\right)$ into the ocean. Considering the Arctic seasonal sea ice extent during the melt period (90 days), we estimate an uptake of atmospheric $\mathrm{CO}_{2}$ of $-10.4 \mathrm{Tg}$ of ${\mathrm{C} \mathrm{yr}^{-1}}^{-}$. This represents an additional uptake of $\mathrm{CO}_{2}$ associated with Arctic sea ice that needs to be further explored and considered in the estimation of the Arctic Ocean's overall $\mathrm{CO}_{2}$ budget.

\section{Introduction}

The Arctic Ocean represents a globally important $\mathrm{CO}_{2}$ sink, with current estimates of net air-to-sea $\mathrm{CO}_{2}$ fluxes between -66 and $-199 \mathrm{TgC}^{-1}$ (Bates and Mathis, 2009; Takahashi et al., 2009). The role of sea ice in these measured air-sea $\mathrm{CO}_{2}$ exchanges still remains uncertain (Parmentier et al., 2013) although recent studies suggest that sea ice may act as an important control on the $\mathrm{CCO}_{2}$ in the ocean surface layer (e.g., Rysgaard et al., 2012b, 2013). In particular, our understanding of inorganic carbon dynamics during the sea ice melt season and the importance to the annual exchange of $\mathrm{CO}_{2}$ across the atmosphere-sea ice-ocean interface is incomplete. Early studies have invoked melt ponds as significant contributors to the Arctic $\mathrm{CO}_{2}$ balance through their uptake of $\mathrm{CO}_{2}$ (Semiletov et al., 2004). However, their impact on inorganic carbon transport through sea ice remains largely uncharacterized, despite the fact that they are a major 
and increasing surface feature of Arctic sea ice during spring and summer (Rösel and Kaleschke, 2012).

Melt ponds cover up to 50-60\% of the Arctic summer sea ice area (Fetterer and Untersteiner, 1998; Eicken et al., 2004). They result from the accumulation of meltwater on sea ice mainly due to melting of snow. Sea ice melt also contributes to the melt pond formation and growth in advanced stages of melt (Rösel and Kaleschke, 2012), driven by increased shortwave absorption during summer (Taylor and Feltham, 2004). During melt pond formation, meltwater either drains into the ocean through cracks and other openings in the sea ice or is collected on the ice surface in depressed areas. This meltwater is nearly free of salt and has a density maximum above the freezing point, resulting in radiative heating favoring convection (Fetterer and Untersteiner, 1998). Convection may be further assisted by winds, increasing temperature erosion of the pond edge and eventually extending the pond area. As sea ice warms during spring, its brine volume increases and meltwater ponds located above the freeboard may drain through vertical seepage to the underlying water (brine flushing, e.g., Fetterer and Untersteiner, 1998), thereby freshening the upper layer of the ocean. This mechanism is believed to be the primary cause for sea ice desalinisation (Untersteiner, 1968; Cox and Weeks, 1974). The input of freshwater to the surface layer of the ocean can lead to the formation of under-ice melt ponds, freshwater lenses trapped under thinner ice areas or in depressions in the bottom of thicker ice (Hanson, 1965; Weeks, 2010). The discharge of meltwater through the ice cover is proportional to the ice permeability and the hydraulic pressure gradient in the brine system (Darcy's law). In summer Arctic sea ice, this gradient is mostly determined by differences in hydraulic head that develop as a result of melt over a non-uniform ice surface (Eicken et al., 2002).

Melt pond formation has a strong impact on the summer energy and mass budgets of an ice cover through the sea ice-albedo feedback mechanism (Fetterer and Untersteiner, 1998; Taylor and Feltham, 2004; Perovich et al., 2011). Melt ponds also alter the physical and optical properties of sea ice (Perovich et al., 2002), have a strong influence of the temporal evolution of sea ice salinity (Untersteiner, 1968; Cox and Weeks, 1974) and affect the salt and heat budget of the ocean mixed layer (Eicken et al., 2002; Perovich et al., 2002). Although a few studies have reported surface flux measurements of $\mathrm{CO}_{2}$ during active surface melt (Semiletov et al., 2004; Geilfus et al., 2012b; Nomura et al., 2013), the role of surface melt ponds and the impact of sea ice melt on both the direction and amount of air-sea $\mathrm{CO}_{2}$ flux is still not well understood.

Semiletov et al. (2004) documented $\mathrm{CO}_{2}$ fluxes of -3.9 to $-51 \mathrm{mmol} \mathrm{m}^{-2}$ day $^{-1}$ (negative flux indicating sea ice uptake of $\mathrm{CO}_{2}$ ) across the sea ice-atmosphere interface over melt ponds in June, near Barrow, Alaska using the chamber method. At that time, brine $p \mathrm{CO}_{2}$ was undersaturated (220$280 \mu \mathrm{atm})$ with respect to the atmosphere (365-375 $\mu \mathrm{atm})$. This undersaturation was attributed to an increase of pho- tosynthetically active radiation (PAR), which was suggested to have reduced the $p \mathrm{CO}_{2}$ in the brine by enhancing photosynthesis (Semiletov et al., 2004). In June 2008, Geilfus et al. (2012b) reported $\mathrm{CO}_{2}$ fluxes over melt ponds and sea ice ranging from -0.02 to $-2.7 \mathrm{mmol} \mathrm{m}^{-2} \mathrm{day}^{-1}$ using the chamber technique over first-year sea ice in the Beaufort Sea. These fluxes were substantially smaller than those reported by Semiletov et al. (2004), but on the same order of magnitude as those reported during period of melt and surface flooding on Antarctic and Arctic sea ice by Nomura et al. (2013). In the study of Geilfus et al. (2012b), sea ice brine and overlying melt ponds were highly undersaturated in $\mathrm{CO}_{2}$ relative to atmospheric levels $\left(p \mathrm{CO}_{2}\right.$ between 0 and $188 \mu \mathrm{atm}$ for brine and between 79 and $348 \mu \mathrm{atm}$ for melt ponds) in $1.2 \mathrm{~m}$ thick landfast sea ice in Amundsen Gulf. At that time, melt ponds were well established and interconnected. It is likely that fresh water originating from internal and surface melting was an important driver of the observed undersaturation in combination with the dissolution of calcium carbonate and primary production. Using micrometeorological techniques, Papakyriakou and Miller (2011) also reported $\mathrm{CO}_{2}$ uptake with the progression of melt over Arctic sea ice, although flux magnitudes are widely diverging from the chamber-based studies highlighted above.

In this study, we examine how melting snow and sea ice and the associated formation of melt ponds affects inorganic carbon dynamics therein and the air-ice $\mathrm{CO}_{2}$ exchange. The evolution of the carbonate system was examined using measurements of total alkalinity (TA) and total dissolved inorganic carbon $\left(T \mathrm{CO}_{2}\right)$ on melted bulk sea ice, as well as in brine and melt ponds samples. In situ $p \mathrm{CO}_{2}$ was measured in bulk sea ice, brine and melt ponds in association with $\mathrm{CO}_{2}$ flux measurements over sea ice and melt ponds. Percolation of meltwater from melt ponds was tracked using the isotopic ratios $\delta \mathrm{D}$ and $\delta^{18} \mathrm{O}$ within bulk sea ice and brine.

\section{Study site, materials and methods}

Field data were collected over first-year landfast sea ice in Resolute Passage, Nunavut, from 3 to 23 June 2012 (Galley et al., 2012). The sampling site $(\sim 100 \mathrm{~m} \times 100 \mathrm{~m})$ was located between Sheringham Point and Griffith Island $\left(74.726^{\circ} \mathrm{N}, 95.576^{\circ} \mathrm{W}\right.$, Fig. 1$)$. At the site, adjacent $5 \mathrm{~m} \times 5 \mathrm{~m}$ areas were chosen for regular sampling for carbonate chemistry determination of ice cores and seawater (in 4-day intervals), while the carbonate chemistry of brine and the surface flux of $\mathrm{CO}_{2}$ were sampled every 2 days. During our survey, the air temperature increased from 0.6 to $4.3^{\circ} \mathrm{C}$ (Fig. 2). During our first ice station (4 June), coarse wet snow was found at the surface of the ice. On 10 June, the first melt ponds were observed (Fig. 2). Once the melt ponds started to form, ice core and brine sampling were limited to areas without melt ponds, referred to as melt hummocks. 


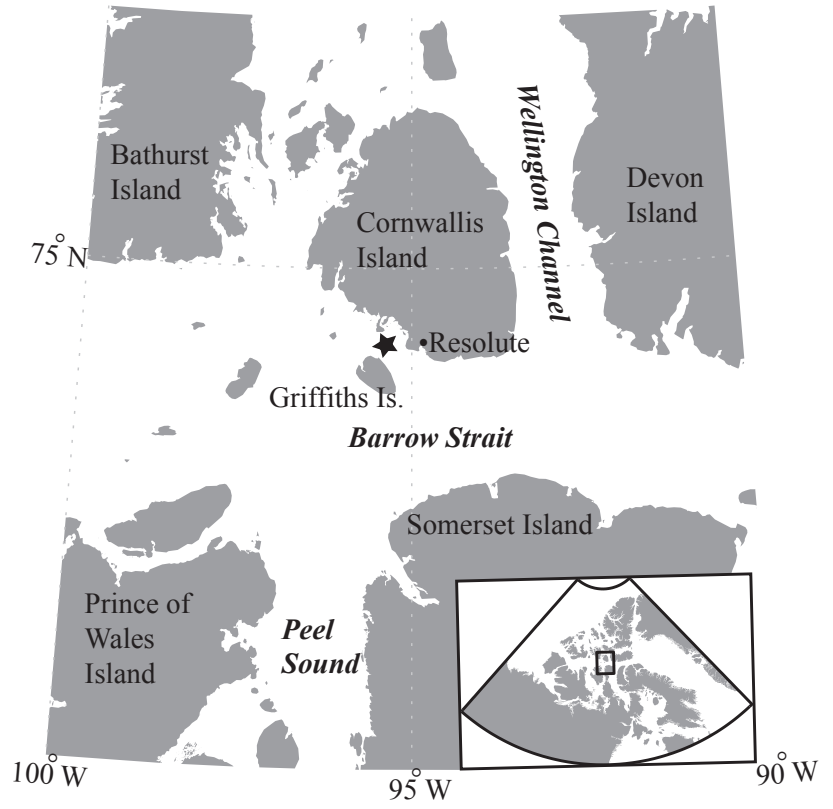

Figure 1. Location map of the sampling area in the Resolute Passage, Nunavut. The sampling site was located between Sheringham Point and Griffith Island $\left(74.726^{\circ} \mathrm{N}, 95.576^{\circ} \mathrm{W}\right)$.

Brine was collected using the sackhole technique (e.g., Gleitz et al., 1995). Sackholes were drilled at incremental depths $(20,40,75,100 \mathrm{~cm})$. Brine from adjacent brine channels and pockets was allowed to seep into the sackholes for 5-10 min before being collected using a peristaltic pump (Cole Palmer ${ }^{\circledR}$, Masterflex - Environmental Sampler). Each sackhole was covered with a plastic lid to prevent snow from falling into the hole.

Sea ice core samples were collected using a MARK II coring system (Kovacs Enterprises ${ }^{\circledR}$ ). Two ice cores were immediately wrapped in polyethylene (PE) bags and stored horizontally at the sampling site at $-20^{\circ} \mathrm{C}$ in a portable freezer (Whynter ${ }^{\circledR} \mathrm{FM}-45 \mathrm{G}$ ) to minimize brine drainage during transport. The first core was dedicated to the analysis of $\mathrm{TA}$ and $T \mathrm{CO}_{2}$. The second core was dedicated to partial pressure of $\mathrm{CO}_{2}$ in bulk ice (noted as $p \mathrm{CO}_{2}[$ bulk]) analysis. Two other cores were collected for in situ sea ice temperature, bulk ice salinity and ikaite $\left(\mathrm{CaCO}_{3} \cdot 6 \mathrm{H}_{2} \mathrm{O}\right)$ content.

Seawater was collected at the ice-water interface through an ice core hole using the peristaltic pump. The same pump was used to collect melt pond samples and an articulated arm was used to collect under-ice melt pond samples. We also collected water column samples at six depths $(2,5,10,25$, $50,80 \mathrm{~m}$ ) using $5 \mathrm{~L}$ Niskin bottles for determination of TA and $T \mathrm{CO}_{2}$. Vertical profiles of water temperature and salinity were measured with a newly calibrated Sea-Bird SBE 19plus V2 conductivity-temperature-depth (CTD) probe.

The $p \mathrm{CO}_{2}$ was measured in situ (noted as $p \mathrm{CO}_{2}$ [in situ]) in brine, melt pond water and under-ice seawater using
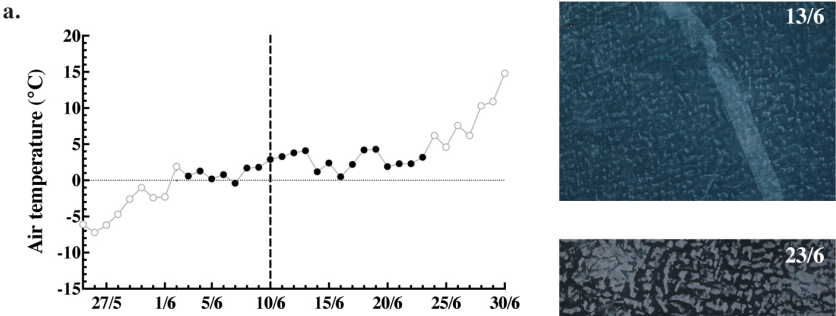

b.
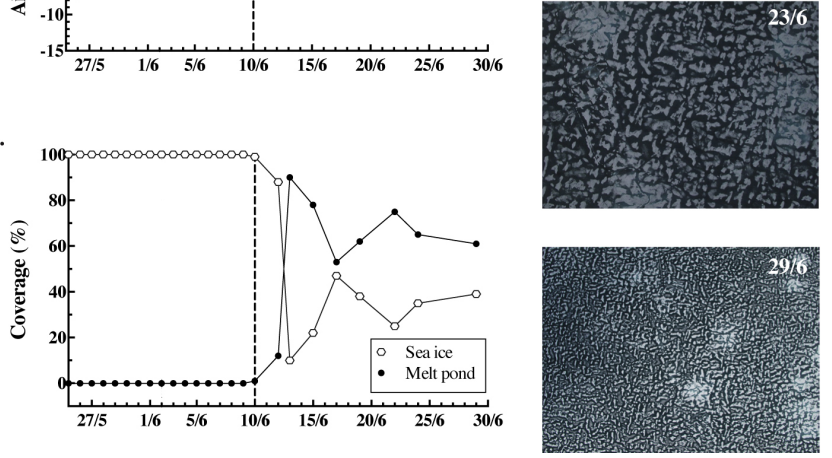

Figure 2. (a) Evolution of the atmospheric temperature in Resolute from the end of May to the end of June 2012. The black dots represent the air temperature during our survey (from 3 to 23 June). (b) Evolution of the melt ponds (black dots) and sea ice (white dots) fraction coverage at the sampling site. The bold dashed line on 10 June represents the initial formation of melt ponds at the surface of the ice cover. Aerial photos were taken over the field study site on 13 June (pond fraction $=0.9$; width of the picture $=4472 \mathrm{~m}$ ), 23 June (pond fraction $=0.65$; width of the picture $=2212 \mathrm{~m}$ ), 29 June (pond fraction $=0.61$; width of the picture $=4426 \mathrm{~m}$ ).

a custom-made equilibration system. The system consists of a membrane contactor equilibrator connected to a nondispersive infrared gas analyzer (IRGA, LI-COR 820) via a closed air loop. Brine and airflow rates through the equilibrator and IRGA are approximately 2 and $3 \mathrm{~L} \mathrm{~min}^{-1}$, respectively. The in situ temperature was measured using a calibrated temperature probe (Testo $720^{\circledR}, \pm 0.1^{\circ} \mathrm{C}$ precision) simultaneously at the inlet and outlet of the equilibrator. Temperature correction of $p \mathrm{CO}_{2}$ was applied assuming that the relation of Copin Montégut (1988) is valid at low temperature and high salinity.

Sea ice temperature was measured in situ immediately after extraction of the ice cores using a calibrated temperature probe (Testo $720^{\circledR}, \pm 0.1^{\circ} \mathrm{C}$ precision) inserted into predrilled holes $(2.5 \mathrm{~cm}$ intervals), perpendicular to core sides. Bulk sea ice salinity and ikaite content was determined on a duplicate ice core sliced into $5 \mathrm{~cm}$ sections directly after extraction and placed in sealed containers which were then placed in a lab fridge to melt at $4^{\circ} \mathrm{C}$. These samples were checked regularly, so that the meltwater temperature never rose above $1-2{ }^{\circ} \mathrm{C}$. Once the samples melted, crystals left in solution were observed on a chilled glass slide under a binocular microscope at room temperature. Finally, the bulk salinity of these samples was measured using a calibrated Thermo Scientific Orion portable salinometer WP-84TPS meter with a precision of \pm 0.1 . The sea ice brine volume was calculated 
according to Cox and Weeks (1983) for temperatures below $-2^{\circ} \mathrm{C}$, and according to Leppäranta and Manninen (1988) between 0 and $-2^{\circ} \mathrm{C}$.

Samples of melted bulk ice, brine, melt ponds, under-ice melt pond water and underlying seawater were brought back to the University of Manitoba for TA and $\mathrm{TCO}_{2}$ analyses. Samples were poisoned with a solution of saturated $\mathrm{HgCl}_{2}$ to prevent any biological activity. The ice core was cut into $10 \mathrm{~cm}$ sections in a cold room $\left(-20^{\circ} \mathrm{C}\right)$, and each section was placed in a gas-tight laminated (Nylon, ethylene vinyl alcohol and polyethylene) plastic bag (Hansen et al., 2000) fitted with a $20 \mathrm{~cm}$ gas-tight Tygon tube and valve. The plastic bag was sealed immediately and excess air was gently removed through the valve using a vacuum pump. The bagged sea ice samples were then melted in the fridge at $4{ }^{\circ} \mathrm{C}$ and the meltwater mixture and bubbles were transferred to a gastight vial (12 mL Exetainer, Labco High Wycombe, UK). TA was determined by potentiometric titration (Haraldsson et al., 1997) with a precision of $\pm 3 \mu \mathrm{mol} \mathrm{kg}{ }^{-1}$, while $T \mathrm{CO}_{2}$ was determined on a $\mathrm{TCO}_{2}$ auto-analyzer (AS-C3, Apollo SciTech) via sample acidification $\left(\mathrm{H}_{3} \mathrm{PO}_{4}\right)$ followed by nondispersive infrared $\mathrm{CO}_{2}$ detection (LI-7000) with a precision of $\pm 2 \mu \mathrm{mol} \mathrm{kg}^{-1}$. Both TA and $T \mathrm{CO}_{2}$ were calibrated with certified reference material from A. G. Dickson at the Scripps Institution of Oceanography.

The ice cores taken for bulk ice $p \mathrm{CO}_{2}$ analysis were cut into $10 \mathrm{~cm}$ sections, stored at $-20^{\circ} \mathrm{C}$ and then shipped frozen so that the bulk ice $p \mathrm{CO}_{2}\left(p \mathrm{CO}_{2}\right.$ [bulk]) could be measured at the Laboratoire de Glaciologie, Université Libre de Bruxelles, using the technique developed by Geilfus et al. (2012a). The general principle of the method is to equilibrate the sea ice samples with a mixture of $\mathrm{N}_{2}$ and $\mathrm{CO}_{2}$ of known concentration (referred to as the "standard gas", $146 \mu \mathrm{atm}$ ) at the in situ temperature and rapidly extract the gases into a Varian 3300 gas chromatograph under vacuum. The ice sample is cut to tightly fit the container $(4 \mathrm{~cm} \times 4 \mathrm{~cm} \times 4.5 \mathrm{~cm})$ to both minimize the headspace volume and keep this headspace constant. The standard gas is injected at 1013 mbar into the container. Then the container with the ice sample is placed in a thermostatic bath at the in situ temperature for $24 \mathrm{~h}$. This timing is chosen to ensure that the sample is re-equilibrated to the brine volume and chemical conditions at the in situ temperature. A quick injection into the gas chromatograph then allows the reconstruction of the equilibrium brine $p \mathrm{CO}_{2}$ at the in situ temperature. This method is only valid if the ice is permeable at the in situ conditions.

Due to differences in the isotopic composition of snowmelt, seawater and sea ice (sea ice is highly depleted in ${ }^{18} \mathrm{O}$ and $\mathrm{D}$ ), the infiltration of meteoric water can be traced through the sea ice system based on stable isotope measurements (Eicken et al., 2002). Therefore, we determined $\delta \mathrm{D}$ and $\delta^{18} \mathrm{O}$ in $2 \mathrm{~mL}$ aliquots of sea ice, brine, under-ice seawater, melt ponds and under-ice melt ponds. Stable isotope measurements were carried out at the University of Manitoba using a Picarro L2130-i analyzer. Samples were calibrated against Vienna Standard Mean Ocean Water (VSMOW) with a precision of $0.1 \%$ for $\delta \mathrm{D}$ and $0.025 \%$ for $\delta^{18} \mathrm{O}$.

$\mathrm{CO}_{2}$ fluxes at the sea ice surface were measured using a LI-COR 8100-103 chamber associated with the LI-8100A soil $\mathrm{CO}_{2}$ flux system. The chamber was connected in a closed loop to the IRGA with an air pump rate at $3 \mathrm{~L} \mathrm{~min}^{-1} . p \mathrm{CO}_{2}$ in the chamber was recorded every second for $15 \mathrm{~min}$ and the flux was computed from the slope of the linear regression of $p \mathrm{CO}_{2}$ against time $\left(r^{2}>0.99\right)$ according to Frankignoulle (1988), taking into account the air volume enclosed within the chamber. The uncertainty of the flux computation due to the standard error on the regression slope was $\pm 3 \%$ on average.

\section{Results}

\subsection{Sea ice}

The average ice thickness at the sampling site, as determined from cores, decreased from $130( \pm 5)$ to $105( \pm 5) \mathrm{cm}$ over the sampling campaign. Over the course of our study period, the vertical temperature gradient within sea ice decreased, leading to a nearly isothermal ice cover by 21 June. The mean ice temperature increased from $-2.9^{\circ} \mathrm{C}$ on 4 June to $-1.5^{\circ} \mathrm{C}$ on 12 June (Fig. 3). From 10 June, the temperature of the top $20 \mathrm{~cm}$ of the ice was slightly negative $\left(-0.5\right.$ to $\left.0^{\circ} \mathrm{C}\right)$, while the rest of the ice thickness remained around $-1.5^{\circ} \mathrm{C}$. The anomalous high values reported in the middle section of the core in June 12 are probably due to warming of the ice during the temperature measurement in the field, as a result of positive air temperature at the time of measurement. Bulk ice salinity ranged from 7.5 to 0 (Fig. 3). The bulk ice salinity of the upper $15 \mathrm{~cm}$ decreased from 5.2 on 4 June to 0.1 on 9 June, then increased to 2.7 on 21 June. The bulk ice salinity of the central section of the ice cover ( 0.2 to $1 \mathrm{~m}$ depth) decreased from 7.5 to 4 during the survey. The bulk ice salinity at the sea ice interface with the water column decreased from 7.4 on 4 June to 2.7 on 21 June. The salinities associated with the high sea ice temperatures resulted in brine volumes greater than $5 \%$ (data not shown).

The $\delta^{18} \mathrm{O}$ and $\delta \mathrm{D}$ isotopic ratios ranged from 1.9 to -23.9 and 2.5 to $-191.2 \%$, respectively (Fig. 3). Profiles of $\delta^{18} \mathrm{O}$ and $\delta \mathrm{D}$ appear to follow the same trend with the lowest values observed in the top $20 \mathrm{~cm}$ of the ice cover. Two low events were reported in the upper $20 \mathrm{~cm}$ of the ice cover. The first was from 8 to 12 June with isotopic ratios of $\delta^{18} \mathrm{O}$ and $\delta \mathrm{D}$ as low as -23.9 and $-191.2 \%$, respectively. The second was on 17 June with $\delta^{18} \mathrm{O}$ and $\delta \mathrm{D}$ of -15.4 and $-133.7 \%$ o respectively. The rest of the ice cover ranged from -2 to $1.9 \%$ for $\delta^{18} \mathrm{O}$ and from -7 to $2.5 \%$ or $\delta \mathrm{D}$.

The mean total alkalinity in melted bulk sea ice $\left(\mathrm{TA}_{\text {ice }}\right)$ for the entire ice column gradually decreased from $408 \mu \mathrm{mol} \mathrm{kg}{ }^{-1}$ on 4 June to $283 \mu \mathrm{mol} \mathrm{kg}{ }^{-1}$ on 21 June (Fig. 3). This decrease of $\mathrm{TA}_{\text {ice }}$ was more pronounced in 

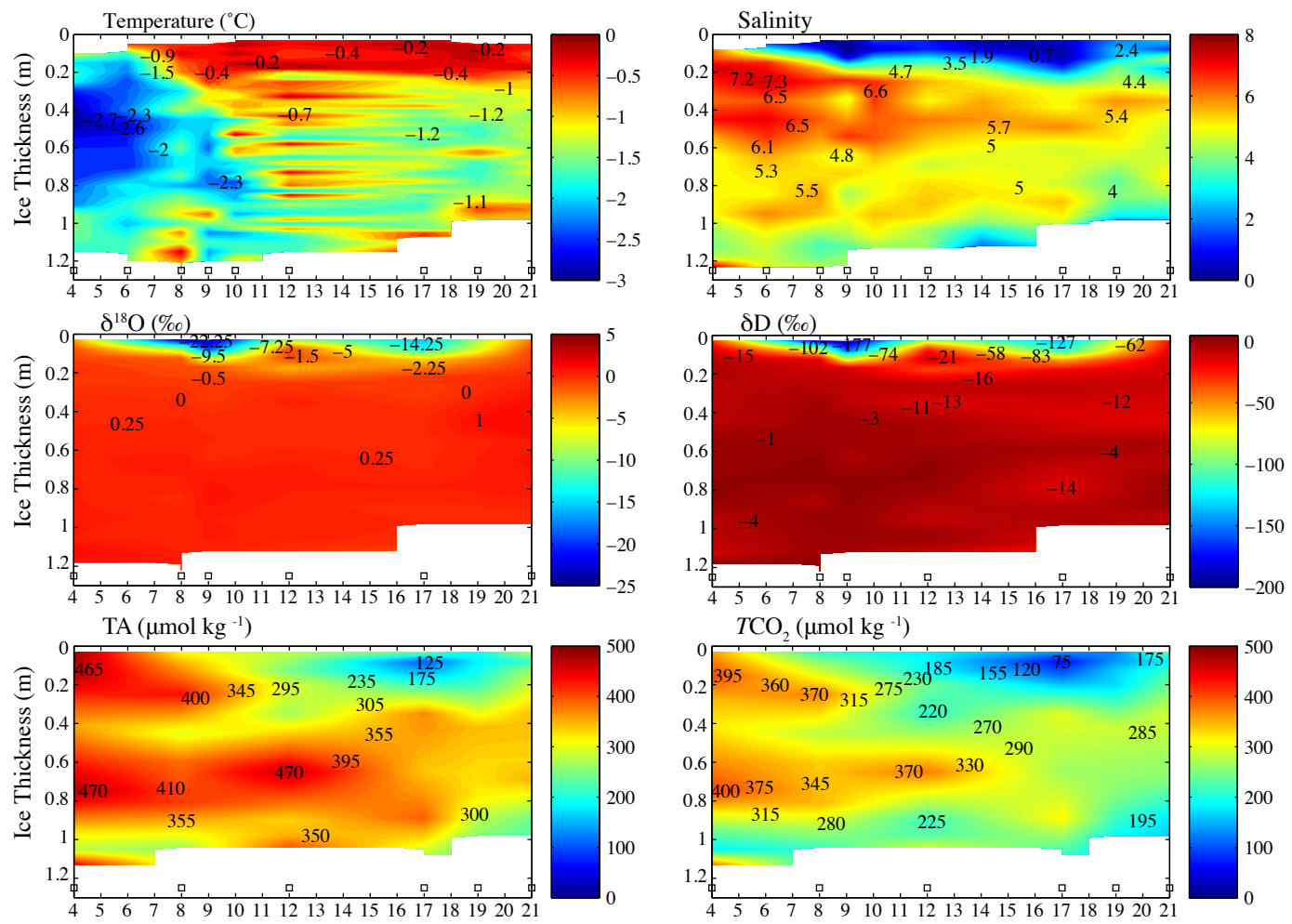

$\mathrm{TCO}_{2}\left(\mu \mathrm{mol} \mathrm{kg}{ }^{-1}\right)$
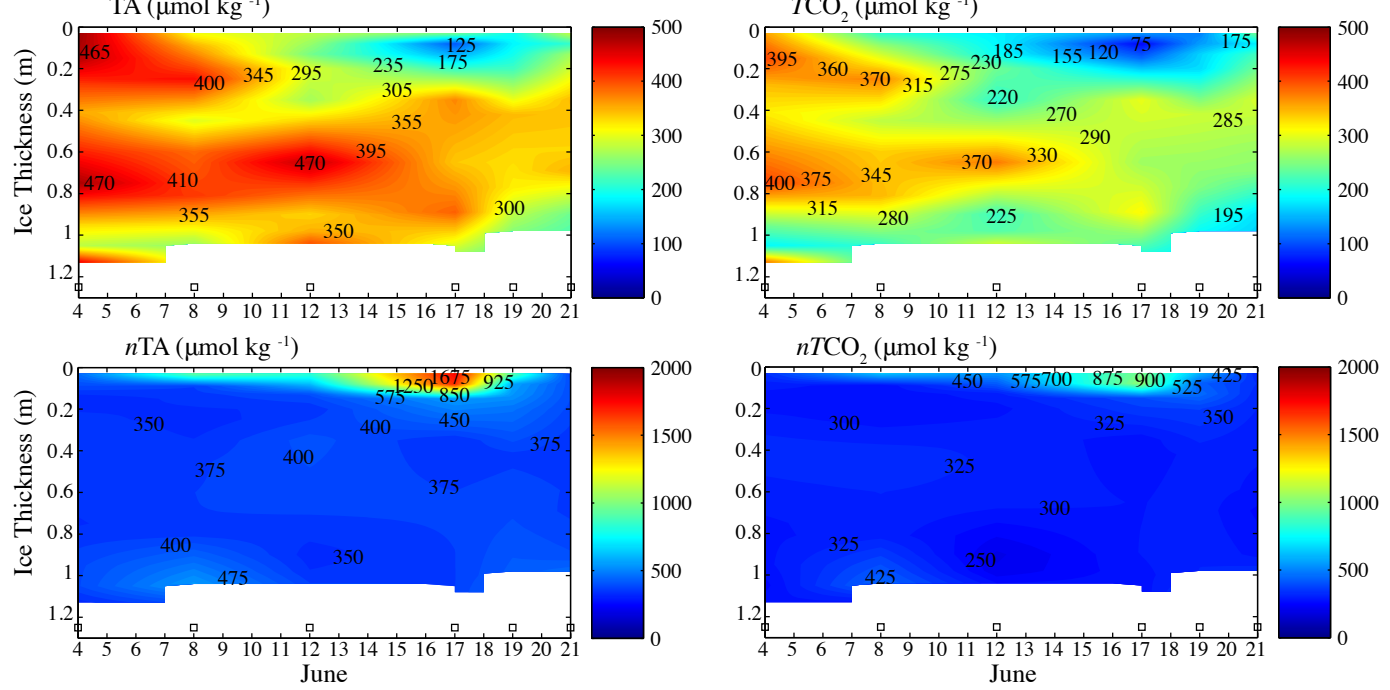

Figure 3. Temporal evolution of sea ice temperature $\left({ }^{\circ} \mathrm{C}\right)$, salinity, isotopic composition of $\delta^{18} \mathrm{O}$ and $\delta D(\% o), \mathrm{TA}_{\mathrm{ice}}$ and $n \mathrm{TA}_{\mathrm{ice}}(\mu \mathrm{mol} \mathrm{kg}-1)$, $T \mathrm{CO}_{2}$ and $n T \mathrm{CO}_{2 \text { ice }}\left(\mu \mathrm{mol} \mathrm{kg}{ }^{-1}\right)$. Open squares on the $x$ axis mark the sampling dates.

the top $20 \mathrm{~cm}$ of the ice cover where the minimum value $\left(106 \mu \mathrm{mol} \mathrm{kg}{ }^{-1}\right)$ was observed on 17 June. The same trend was observed for the total inorganic carbon $\left(\mathrm{TCO}_{2 \text { ice }}\right.$, Fig. 3). The mean $\mathrm{TCO}_{2 \text { ice }}$ of the entire ice column decreased from $332 \mu \mathrm{mol} \mathrm{kg}{ }^{-1}$ on 4 June to $225 \mu \mathrm{mol} \mathrm{kg}{ }^{-1}$ on 21 June. The minimum values were observed on 17 June, with a mean concentration of $189 \mu \mathrm{mol} \mathrm{kg}{ }^{-1}$. To discard concentrationdilution effects, we normalized $\mathrm{TA}_{\text {ice }}$ and $\mathrm{TCO}_{2 \text { ice }}$ to the mean bulk salinity of our sea ice samples (salinity $=5$, noted as $n \mathrm{TA}_{\text {ice }}$ and $n T \mathrm{CO}_{2 \text { ice }}$, respectively). The main change observed in normalized values occurred in the top $20 \mathrm{~cm}$. From 4 to 17 June, $n \mathrm{TA}_{\text {ice }}$ and $n T \mathrm{CO}_{2 \text { ice }}$ increased from 468 and $345 \mu \mathrm{mol} \mathrm{kg}{ }^{-1}$ to 1762 and $1041 \mu \mathrm{mol} \mathrm{kg}{ }^{-1}$ while the rest of the ice cover ranged from 337 to $564 \mu \mathrm{mol} \mathrm{kg}^{-1}$ and from 219 to $461 \mu \mathrm{mol} \mathrm{kg}^{-1}$, respectively. On 19 and 21 June, in the top $20 \mathrm{~cm}, n \mathrm{TA}_{\text {ice }}$ and $n T \mathrm{CO}_{2 \text { ice }}$ decreased to 376 and $323 \mu \mathrm{mol} \mathrm{kg}^{-1}$.
From $\mathrm{TA}_{\text {ice }}$ and $\mathrm{TCO}_{2 \text { ice }}$, we computed a bulk ice $p \mathrm{CO}_{2}$ (noted as $p \mathrm{CO}_{2}$ [bulk_calc]) using the $\mathrm{CO}_{2}$ dissociation constants of Mehrbach et al. (1973) refitted by Dickson and Millero (1987) and correcting the $p \mathrm{CO}_{2}$ for temperature using the relation of Copin Montégut (1988). This $p \mathrm{CO}_{2}$ [bulk_calc] ranged from 0 to $32 \mu \mathrm{atm}$ (Fig. 4). On a duplicate ice core, the $p \mathrm{CO}_{2}$ [bulk] was also measured in solid ice at the in situ temperature, using the sample equilibration technique developed by Geilfus et al. (2012a). The $p \mathrm{CO}_{2}$ [bulk] ranged from 6 to $182 \mu$ atm (Fig. 4).

We observed few crystals in the ice, which dissolved within a few minutes at room temperature. Due to technical problems we were unable to take any pictures of the crystals. However, as the overall aspect of these crystals was the same as the crystals found in Geilfus et al. (2013a, b) and Rysgaard et al., (2014), and because they dissolved quickly at room 

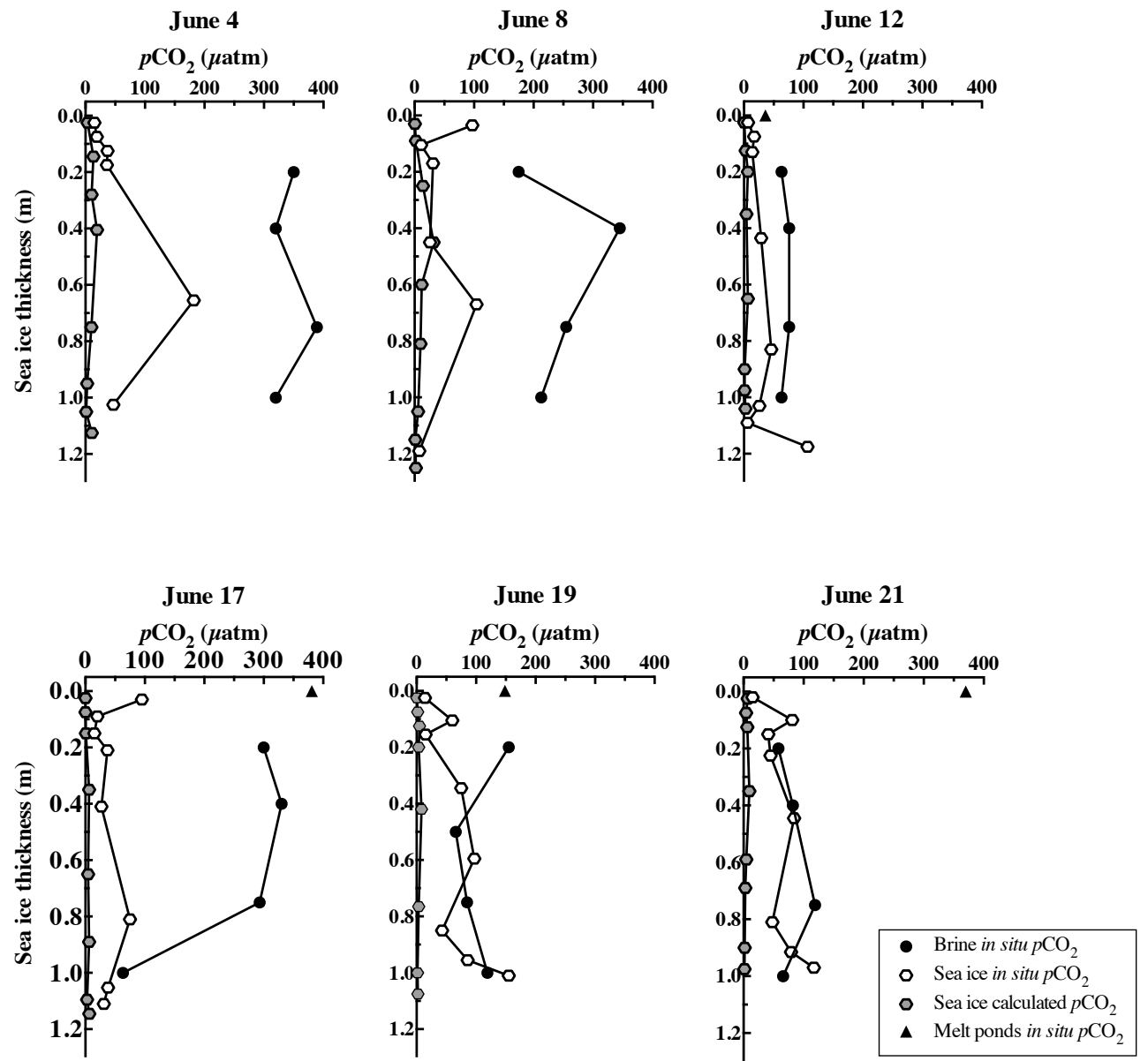

Figure 4. Profiles of sea ice $p \mathrm{CO}_{2}$ [bulk_calc] (calculated from $\mathrm{TA}_{\text {ice }}$ and $\mathrm{TCO}_{2 \text { ice }}$, grey hexagons), sea ice $p \mathrm{CO}_{2}$ [bulk] (white hexagons), brine and melt ponds $p \mathrm{CO}_{2}$ [in situ] (black dots and triangles, respectively).

temperature, we assumed they were ikaite (after Rysgaard et al., 2012b, 2013, 2014).

\subsection{Brine}

From 4 to 10 June, the brine salinity decreased from 55 to 23 (Fig. 5). Starting on 10 June, low brine salinities (ranging from 1.6 to 11.8 ) were found at $20 \mathrm{~cm}$ depth, while deeper brine salinities ranged from 11 to 30 , except on 17 June where low salinity were also found at $40 \mathrm{~cm}$ depth. The $\delta^{18} \mathrm{O}$ and $\delta \mathrm{D}$ isotopic ratios ranged from -1.5 to $-15.2 \%$ and from -15.5 to $-118.2 \%$, respectively (Fig. 5). Both profiles appear to be similar, with the lowest values observed at $20 \mathrm{~cm}$ depth on 10 June ( -15.2 and $-118.1 \%$, respectively) and at 20 and $40 \mathrm{~cm}$ depth on 17 June $(-10.4$ and $-87.5 \%$, respectively).

From 4 to 21 June, $\mathrm{TA}_{\mathrm{br}}$ and $\mathrm{TCO}_{2 \mathrm{br}}$ decreased from their maximum values of 3487 and $3189 \mu \mathrm{mol} \mathrm{kg}^{-1}$ to 234 and $270 \mu \mathrm{mol} \mathrm{kg}^{-1}$, respectively (Fig. 5). Two periods of low concentrations were observed during our survey. On 10 June, $\mathrm{TA}_{\mathrm{br}}$ and $\mathrm{TCO}_{2 \mathrm{br}}$ minimums of 501 and $401 \mu \mathrm{mol} \mathrm{kg}{ }^{-1}$ re- spectively occurred at $20 \mathrm{~cm}$. On $17 \mathrm{June}, \mathrm{TA}_{\mathrm{br}}$ and $\mathrm{TCO}_{2 \mathrm{br}}$ were 240 and $275 \mu \mathrm{mol} \mathrm{kg}^{-1}$ respectively at 20 and $40 \mathrm{~cm}$. These two minima in $\mathrm{TA}_{\mathrm{br}}$ and $\mathrm{TCO}_{2 \mathrm{br}}$ coincided with maximums in $n \mathrm{TA}_{\mathrm{br}}$ and $n T \mathrm{CO}_{2 \mathrm{br}}$. On $10 \mathrm{June}, n \mathrm{TA}_{\mathrm{br}}$ and $n T \mathrm{CO}_{2 \mathrm{br}}$ were 596 and $478 \mu \mathrm{molkg}{ }^{-1}$, and on $17 \mathrm{June}$, $n \mathrm{TA}_{\text {br }}$ and $n T \mathrm{CO}_{2 \mathrm{br}}$ were 874 and $900 \mu \mathrm{mol} \mathrm{kg}{ }^{-1}$.

The brine $p \mathrm{CO}_{2}[\mathrm{in}$ situ] was undersaturated with respect to the atmosphere (395 $\mu \mathrm{atm}$ in June 2012) with values ranging from 20 to $389 \mu \mathrm{atm}$ (Figs. 4, 5). From 4 to 12 June, the mean brine $p \mathrm{CO}_{2}$ [in situ] decreased from 344 to $70 \mu \mathrm{atm}$. Then, it increased to $246 \mu \mathrm{atm}$ on 17 June before decreasing to $81 \mu$ atm on 21 June.

\subsection{Melt ponds}

On 10 June, melt ponds started to form and were present during the rest of the survey. The melt pond salinity increased from 1.5 to 2.4 during the survey with temperatures ranging from 0 to $0.4^{\circ} \mathrm{C}$. The $\delta^{18} \mathrm{O}$ and $\delta \mathrm{D}$ isotopic ratios ranged from -3.8 to $-10.1 \%$ and from -40.6 to $-93.4 \%$ with the 

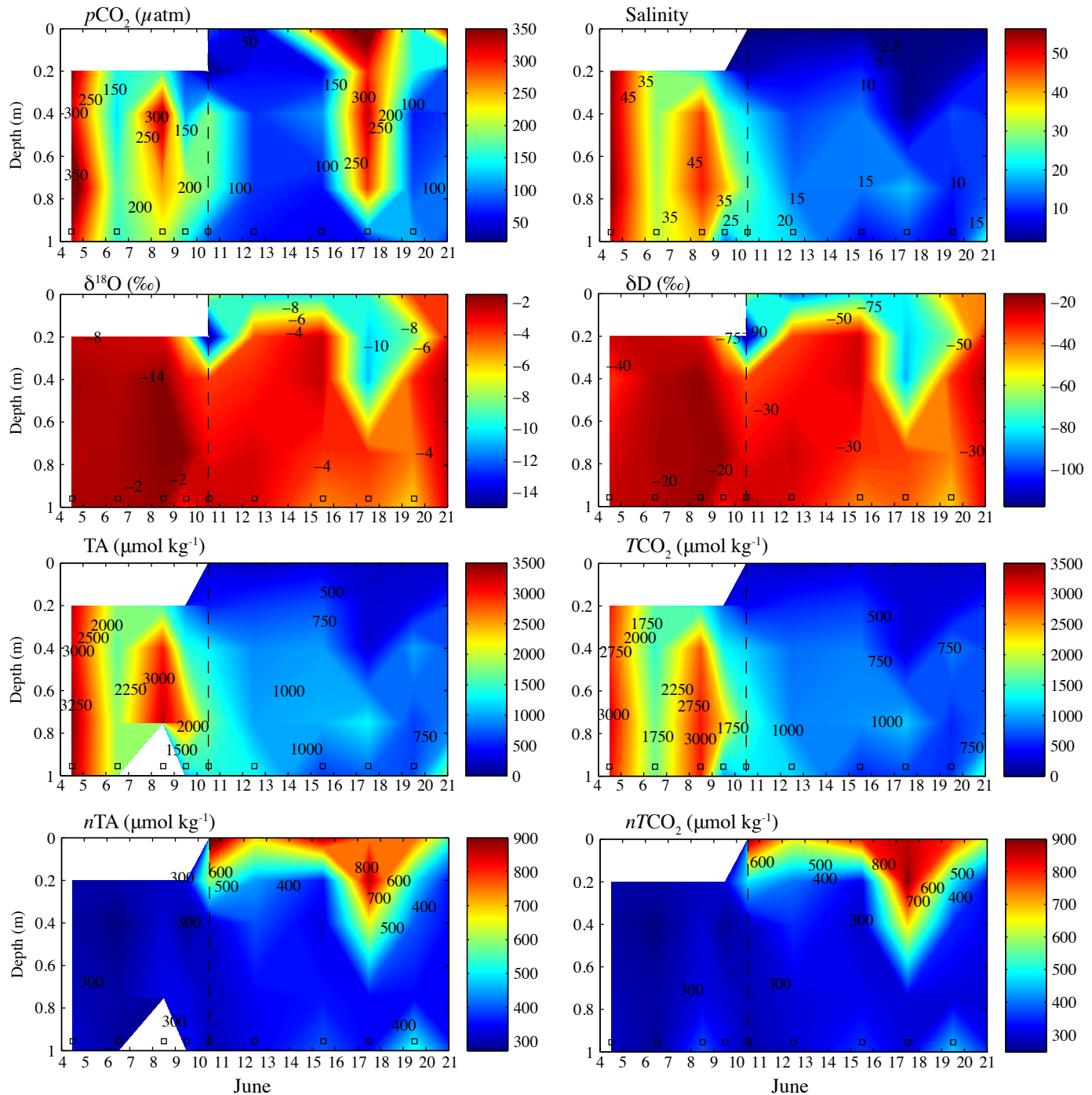

Figure 5. Temporal evolution of brine ( $0.2,0.4,0.75$ and $1 \mathrm{~m}$ depth) and melt ponds $(0 \mathrm{~m}) p \mathrm{CO}_{2}[\mathrm{in}$ situ] ( $\mu$ atm), salinity, isotopic composition of $\delta^{18} \mathrm{O}$ and $\delta D(\% o)$, TA and $n \mathrm{TA}\left(\mu \mathrm{mol} \mathrm{kg}{ }^{-1}\right), T \mathrm{CO}_{2}$ and $n T \mathrm{CO}_{2}\left(\mu \mathrm{mol} \mathrm{kg}^{-1}\right)$. Open squares on the $x$ axis mark the sampling dates.

minimum values observed on 12 June and the maximum values on 21 June (Fig. 5).

$\mathrm{TA}_{\mathrm{mp}}$ and $\mathrm{TCO}_{2 \mathrm{mp}}$ ranged from 219 to $332 \mu \mathrm{mol} \mathrm{kg}^{-1}$ and from 206 to $306 \mu \mathrm{mol} \mathrm{kg}^{-1}$, respectively. $n \mathrm{TA}$ and $n T \mathrm{CO}_{2}$ in the melt ponds ranged from 489 to $972 \mu \mathrm{mol} \mathrm{kg}-1$ and 562 to $918 \mu \mathrm{mol} \mathrm{kg}{ }^{-1}$, respectively (Fig. 5).

Melt pond water was also undersaturated with respect to the atmosphere, with a $p \mathrm{CO}_{2}$ [in situ] ranging from 36 to $381 \mu \mathrm{atm}$. During the initial formation of melt ponds, their $p \mathrm{CO}_{2}[$ in situ] was low $(36-84 \mu \mathrm{atm})$ but increased to $381 \mu \mathrm{atm}$ on 17 June before fluctuating between 150 and $370 \mu$ atm (Fig. 5).

\subsection{Underlying seawater}

During the survey, the temperature of the seawater layer immediately underlying the sea ice increased from -1.7 to $-1.4^{\circ} \mathrm{C}$. The salinity of this layer decreased gradually from 33.2 to 31.4 while the salinity of the water column below $10 \mathrm{~m}$ changed much less (Fig. 6).

The $\delta^{18} \mathrm{O}$ and $\delta \mathrm{D}$ isotopic ratio of the surface layer decreased gradually from their respective maximums of -1.3 and $-17.3 \%$ to -2.2 and $-19.5 \%$ on 20 June. Deeper layers of the water column ranged from -1.5 and $-14.9 \%$ to -1.9 and $-18.9 \%$, respectively (Fig. 6).

$\mathrm{TA}_{\mathrm{sw}}$ and $\mathrm{TCO}_{2 \mathrm{sw}}$ ranged from 2021 and $1920 \mu \mathrm{molkg}^{-1}$ to 2239 and $2167 \mu \mathrm{mol} \mathrm{kg}{ }^{-1}$, respectively. On 20 June, a strong decrease in $\mathrm{TA}_{\mathrm{sw}}$ and $\mathrm{TCO}_{2 \mathrm{sw}}$ was observed, leading to the observed minimum values at the surface of the wa- 

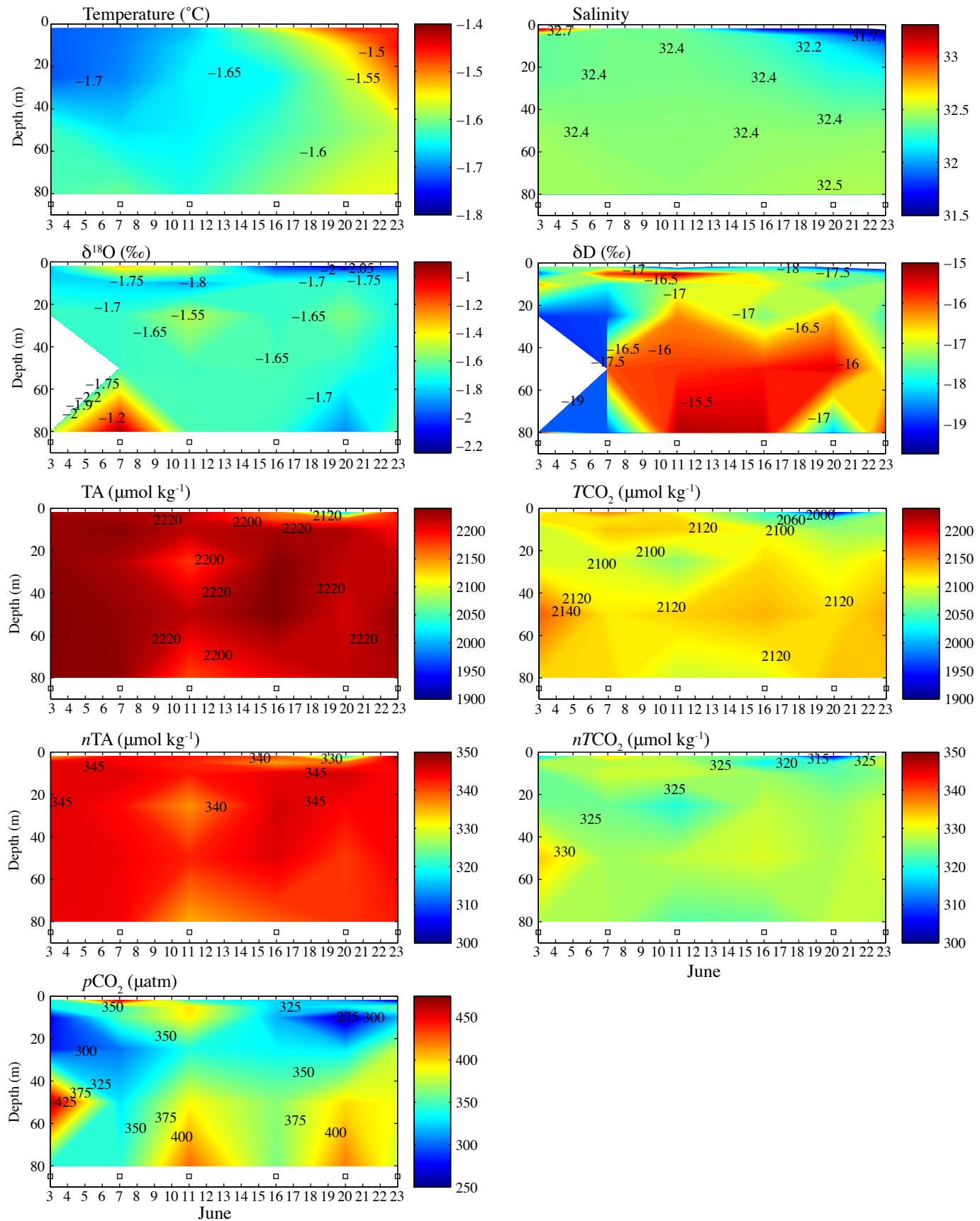

Figure 6. Temporal evolution of water column temperature $\left({ }^{\circ} \mathrm{C}\right)$, salinity, isotopic composition of $\delta^{18} \mathrm{O}$ and $\delta D(\% o)$, TA and $n \mathrm{TA}$ $\left(\mu \mathrm{mol} \mathrm{kg}{ }^{-1}\right), T \mathrm{CO}_{2}$ and $n T \mathrm{CO}_{2}\left(\mu \mathrm{mol} \mathrm{kg}{ }^{-1}\right)$ and calculated $p \mathrm{CO}_{2}(\mu \mathrm{atm})$. Open squares on the $x$ axis mark the sampling dates.

ter column. The normalized $\mathrm{TA}_{\mathrm{sw}}$ and $\mathrm{TCO}_{2 \mathrm{sw}}\left(n \mathrm{TA}_{\mathrm{sw}}\right.$ and $n T \mathrm{CO}_{2 \mathrm{sw}}$ to salinity 5 are shown (Fig. 6) to allow direct comparison with the sea ice and brine data) ranged from 319 to $350 \mu \mathrm{mol} \mathrm{kg}{ }^{-1}$ and 303 to $333 \mu \mathrm{mol} \mathrm{kg}^{-1}$, respectively.

The $p \mathrm{CO}_{2}$ [in situ] of the water column ranged from 259 to $469 \mu \mathrm{atm}$. The top $2 \mathrm{~m}$ of the seawater column was mainly undersaturated with respect to the atmosphere, except on
7 June when the $p \mathrm{CO}_{2}$ [in situ] was $455 \mu$ atm. From there, the $p \mathrm{CO}_{2}$ [in situ] decreased to $269 \mu \mathrm{atm}$ on 23 June (Fig. 6).

\subsection{Air-ice $\mathrm{CO}_{2}$ fluxes}

$\mathrm{CO}_{2}$ fluxes were systematically measured over sea ice and melt ponds (Fig. 7) throughout the campaign. Initially, $\mathrm{CO}_{2}$ fluxes over sea ice were on average $-1.4 \mathrm{mmol} \mathrm{m}^{-2} \mathrm{~d}^{-1}$. During the initial formation of melt ponds, the fluxes over 


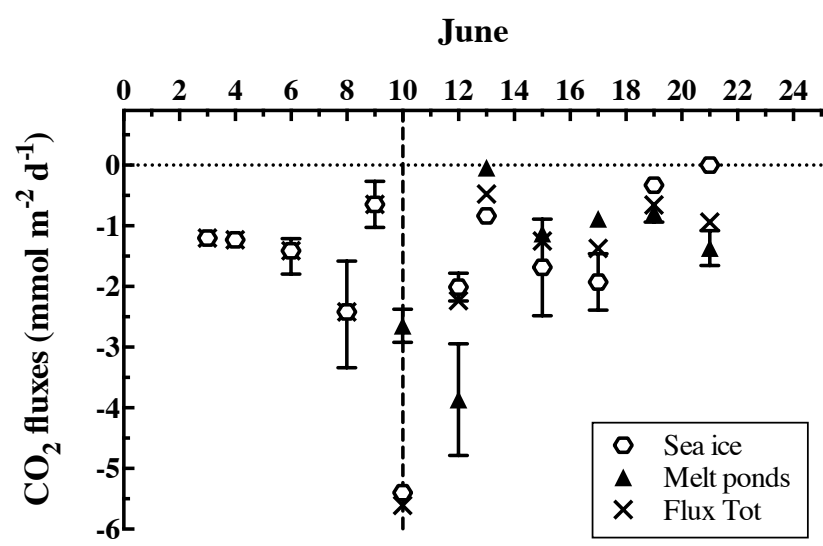

Figure 7. $\mathrm{CO}_{2}$ fluxes $\left(\mathrm{mmolm} \mathrm{m}^{-2} \mathrm{day}^{-1}\right)$ measured over sea ice (white hexagons), melt ponds (black triangles). The total fluxes are represented by the black cross.

sea ice peaked at $-5.4 \mathrm{mmolm}^{-2} \mathrm{day}^{-1}$ on 10 June and $-2 \mathrm{mmolm}^{-2} \mathrm{day}^{-1}$ on 12 June. Over melt ponds, the initial uptake of $\mathrm{CO}_{2}$ was significant at $-2.9 \mathrm{mmol} \mathrm{m}^{-2}$ day $^{-1}$ on 10 June and $-4.8 \mathrm{mmol} \mathrm{m}^{-2} \mathrm{day}^{-1}$ on 12 June. Thereafter the uptake of $\mathrm{CO}_{2}$ by sea ice and melt ponds decreased over time and stabilized at around $-1 \mathrm{mmolm}^{-2} \mathrm{day}^{-1}$.

\section{Discussion}

Seasonally rising sea ice temperature was associated with decreasing bulk ice salinity until ultimately values approached 0 at the surface of the ice cover (Fig. 3). The percolation of snowmelt through the ice cover and its refreezing into the ice matrix formed interposed ice (Landy et al., 2014). The formation of interposed ice as described by Freitag and Eicken (2003) and Polashenski et al. (2012) could explain the low salinity and low values of $\delta^{18} \mathrm{O}$ (down to $-23.9 \%$ ) and $\delta \mathrm{D}$ (down to $-191.2 \%$ ) observed in the upper $20 \mathrm{~cm}$ of the ice cover. These values are much lower than typical bulk sea ice values $\left(\delta^{18} \mathrm{O}\right.$ from -0.69 to $1.92 \%$ and $\delta \mathrm{D}$ from -24.1 to $2.53 \%$, Fig. 3).

Within the brine system, the low isotopic composition observed at $20 \mathrm{~cm}$ depth on 10 June $(-15.2$ and $-118.1 \%$, respectively, after melt pond formation) and at 20 and $40 \mathrm{~cm}$ depth on 17 June $(-10.4$ and $-87.5 \%$, respectively) can be explained by the percolation of melt pond water $(-10.1$ and $-93.4 \%$, respectively) into the underlying sea ice cover (Fig. 5). The combination of negative isotopic ratios with low salinities and warm ice temperatures $\left(\sim 0^{\circ} \mathrm{C}\right)$ collectively suggest that meltwater percolated into the ice cover, at least to a depth of $40 \mathrm{~cm}$.

Previous work has shown brine $p \mathrm{CO}_{2}$ to change dramatically over the period between sea ice formation and melting (Nomura et al., 2010a; Geilfus et al., 2012b). Increased ice temperatures decrease brine concentration and brine $p \mathrm{CO}_{2}$. Brine dilution will also promote the dissolution of ikaite that may have precipitated in the sea ice, further decreasing the $p \mathrm{CO}_{2}$ following the reaction:

$\mathrm{CaCO}_{3} \cdot 6 \mathrm{H}_{2} \mathrm{O}+\mathrm{CO}_{2} \rightleftharpoons \mathrm{Ca}^{2+}+2 \mathrm{HCO}_{3}^{-}+5 \mathrm{H}_{2} \mathrm{O}$.

There are several reports of ikaite precipitation in Arctic sea ice (Dieckmann et al., 2010; Rysgaard et al., 2012a, 2013; Geilfus et al., 2013a, b; Søgaard et al., 2013). In this study, however, only a few crystals were observed and they dissolved within minutes after melting the sea ice. The overall morphology of these crystals are easily recognized as ikaite due to their similarity to crystals identified as ikaite by X-ray diffraction during other campaigns (after Geilfus et al., 2013a, b; Rysgaard et al., 2013, 2014). It is not surprising that only small amounts of ikaite crystals were observed in the ice samples as the combination of elevated temperature and brine dilution associated with melting would support the dissolution of ikaite (Rysgaard et al., 2012a). Rysgaard et al. (2014) linked the amount of ikaite content in the ice to the ice temperature, suggesting that as the ice warms up/cools down, ikaite crystals will dissolve/precipitate.

The concentrations of TA and $T \mathrm{CO}_{2}$ reported in melted bulk sea ice, brine and melt ponds in this study are in the same range as those reported from previous studies in the Canadian Archipelago (Rysgaard et al., 2007; Miller et al., 2011; Geilfus et al., 2012b, 2013a). Increased temperatures and decreased salinity promote the overall decrease in $\mathrm{TA}_{\text {ice }}$ and $\mathrm{TCO}_{2 \text { ice }}$ concentrations (Fig. 3). The relatively constant $n \mathrm{TA}_{\text {ice }}$ and $n T \mathrm{CO}_{2 \text { ice }}$ values suggest that the dilution effect dominated. However, the reduction in $\mathrm{TA}_{\text {ice }}$ and $\mathrm{TCO}_{2 \text { ice }}$ in the top $20 \mathrm{~cm}$ of the ice cover was more pronounced after the onset of melt pond formation and the formation of interposed ice. These low $\mathrm{TA}_{\text {ice }}$ and $\mathrm{TCO}_{2 \text { ice }}$ concentrations are associated with a significant increase of $n \mathrm{TA}_{\text {ice }}$ and $n T \mathrm{CO}_{2 \text { ice }}$.

Decreased brine salinity in response to seasonal warming promoted a decrease in $\mathrm{TA}_{\mathrm{br}}$ and $\mathrm{TCO}_{2 \mathrm{br}}$ (Geilfus et al., 2012b). Minima in $\mathrm{TA}_{\mathrm{br}}$ and $\mathrm{TCO}_{2 \mathrm{br}}$ were associated with minimum isotopic ratios of $\delta^{18} \mathrm{O}$ and $\delta \mathrm{D}$; hence, we attribute the reduction in carbonate species largely to the percolation of fresh meltwater from surface melt ponds into the upper portion of the sea ice volume (Fig. 5). $n \mathrm{TA}_{\mathrm{br}}$ and $n T \mathrm{CO}_{2 \mathrm{br}}$ remained relatively constant until the period of meltwater percolation, which corresponded to a significant increase in both $n \mathrm{TA}_{\mathrm{br}}$ and $n T \mathrm{CO}_{2 \mathrm{br}}$.

Melt pond formation and the subsequent percolation of meltwater into the ice cover affect $\mathrm{TA}_{\mathrm{br}}$ and $\mathrm{TCO}_{2 \mathrm{br}}$ and also appear to affect the in situ brine $p \mathrm{CO}_{2}$ (Fig. 5). From 4 to 10 June, the decrease of the brine $p \mathrm{CO}_{2}$ [in situ] is mainly due to the concurrent decrease in brine salinity associated with rising ice temperatures and the dissolution of ikaite. As melt ponds begin to form, their initial $p \mathrm{CO}_{2}$ is much lower (36-84 $\mu \mathrm{atm})$ than the atmosphere $(395 \mu \mathrm{atm})$. The percolation of low $p \mathrm{CO}_{2}$ melt pond water into the ice matrix resulted in a strong decrease in the brine $p \mathrm{CO}_{2}$ [in situ] observed at $20 \mathrm{~cm}$ depth on 9 and 10 June. However, over time, the melt 

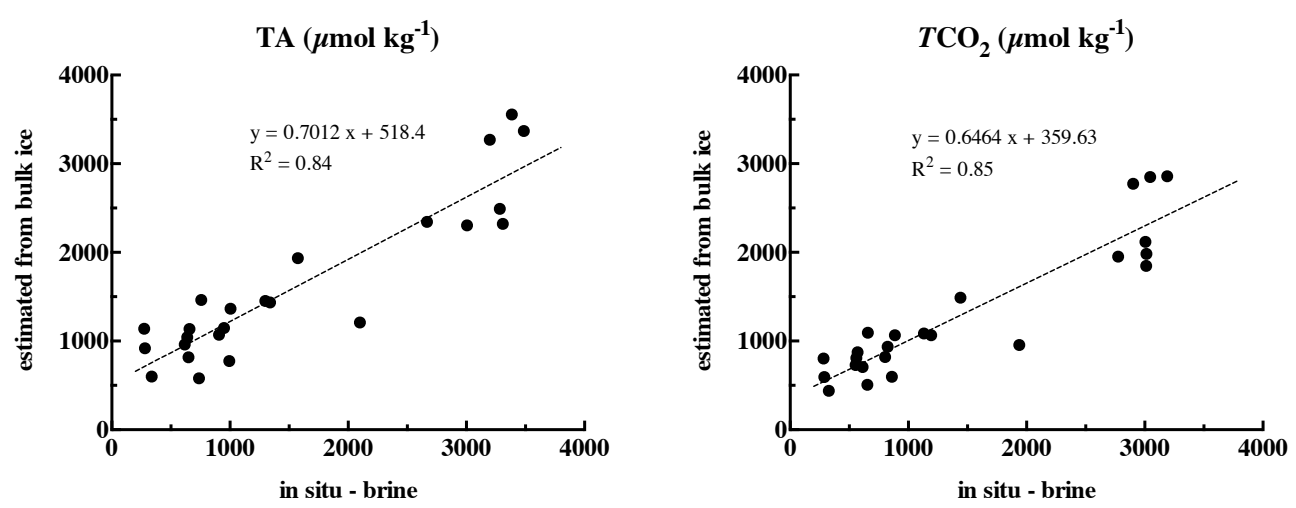

Figure 8. Comparison between brine $\mathrm{TA}$ and $T \mathrm{CO}_{2}$ measured in brine collected using the sackholes technique and the brine $\mathrm{TA}$ and $T \mathrm{CO}_{2}$ estimated from $\mathrm{TA}_{\text {ice }}, \mathrm{TCO}_{2 \text { ice }}$ and the brine volume.

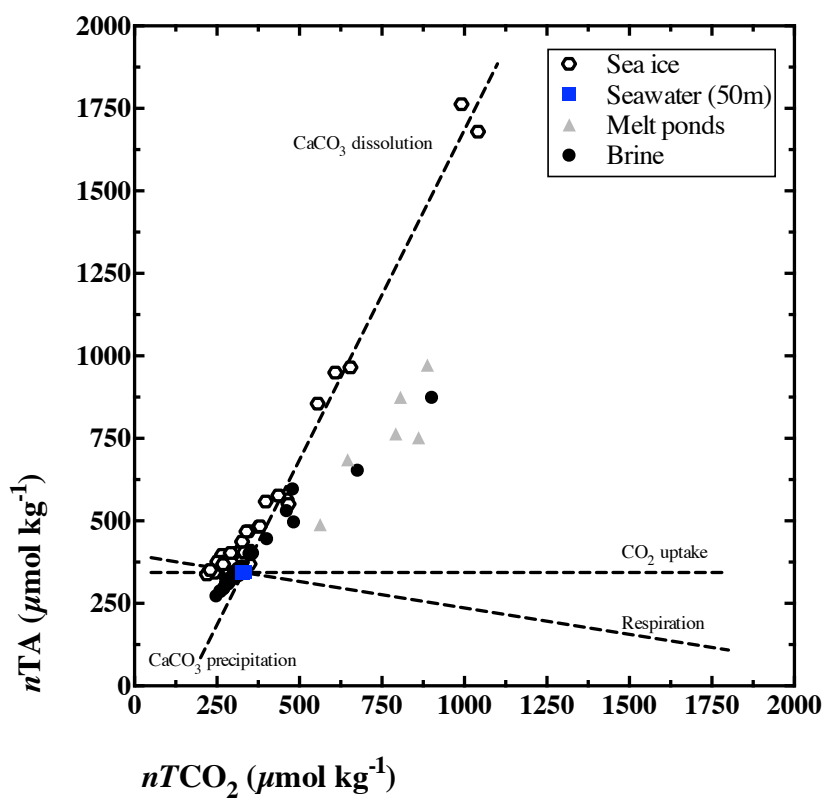

Figure 9. Relationship between the $n T \mathrm{CO}_{2}$ and $n \mathrm{TA}\left(\mu \mathrm{molkg} \mathrm{kg}^{-1}\right)$ in bulk sea ice (white hexagons), melt ponds (grey triangles) and brine samples (black dots). The different dashed lines represent the theoretical evolution of $n \mathrm{TA}: n T \mathrm{CO}_{2}$ ratio following the precipitation/dissolution of calcium carbonate, release/uptake of $\mathrm{CO}_{2(\mathrm{~g})}$ and biological photosynthesis/respiration.

pond $p \mathrm{CO}_{2}$ [in situ] increased as it continued to equilibrate with the atmosphere (Fig. 5). The subsequent percolation of this higher $p \mathrm{CO}_{2}$ meltwater into the ice matrix resulted in an increase in brine $p \mathrm{CO}_{2}$ within the sea ice observed on 17 June. The melt pond $p \mathrm{CO}_{2}$ [in situ] decreased slightly (150 $\mu$ atm on 19 June) as did the brine $p \mathrm{CO}_{2}$ (to $<100 \mu \mathrm{atm}$ ) as a result of meltwater being added to the pond. By 21 June, the $p \mathrm{CO}_{2}$ in the melt pond had increased as a result of atmospheric $\mathrm{CO}_{2}$ uptake.

The sea ice $p \mathrm{CO}_{2}$ [bulk] measured in solid ice samples (Fig. 4) are in the same range as those reported by Geilfus et al. (2012a) on landfast sea ice sampled during the same season in Barrow, Alaska. The ice characteristics in the Barrow study were similar to this Resolute Passage survey: a nearly isothermal ice cover (approaching $0^{\circ} \mathrm{C}$ ), low salinity in the sea ice surface layer $(0-20 \mathrm{~cm})$ and melt ponds at the surface of the ice (Zhou et al., 2013). Crabeck et al. (2014) also reported sea ice $p \mathrm{CO}_{2}[$ bulk] from SW Greenland. However, the concentrations reported in this work are on the lower end compared with the concentrations of 77-330 $\mu$ atm reported by Crabeck et al. (2014) due in part to warmer sea ice leading to a lower $p \mathrm{CO}_{2}$ due to brine dilution by fresh meltwater (Fig. 5) and/or dissolution of ikaite. These concentrations can be compared with the sea ice $p \mathrm{CO}_{2}$ [bulk_calc] (Fig. 4). However, the sea ice $p \mathrm{CO}_{2}$ [bulk_calc] values rely on the validity of four equilibrium constants of the aqueous carbonate system. The thermodynamic constants are assumed to be valid at subzero temperatures, but this assumption needs to be tested. Moreover, the sea ice $p \mathrm{CO}_{2}$ [bulk_calc], which is derived from TA and $T \mathrm{CO}_{2}$ analyses, is not representative of the in situ concentration because the ice sample must be melted. Moreover, melting samples will dissolve ikaite crystals that may have formed, which will strongly impact both the TA and the $T \mathrm{CO}_{2}$ of the resulting meltwater. On the contrary, the sea ice $p \mathrm{CO}_{2}[$ bulk] measured the $\mathrm{CO}_{2}$ concentration at the in situ temperature, and therefore takes into account the $\mathrm{CO}_{2}$ dissolved within the brine as well as the gaseous $\mathrm{CO}_{2}$ (bubbles) in the ice sample. The average $p \mathrm{CO}_{2}$ [bulk_calc] is in the lower end of the $p \mathrm{CO}_{2}$ [bulk] range. However, both sea ice $p \mathrm{CO}_{2}$ [bulk_calc] and $p \mathrm{CO}_{2}$ [bulk] show an overall drop in $p \mathrm{CO}_{2}$ associated with brine dilution and the dissolution of ikaite. While the ice $p \mathrm{CO}_{2}$ [bulk_calc] only shows a slight decrease over time, the ice $p \mathrm{CO}_{2}[$ bulk] reveals that larger changes may occur, especially in the upper $20 \mathrm{~cm}$ of the ice cover (Fig. 4). The ice $p \mathrm{CO}_{2}$ [bulk] and brine $p \mathrm{CO}_{2}$ [in situ] differ in that a significant decrease in the brine $p \mathrm{CO}_{2}$ [in situ] was observed on 12 June just after melt pond formation, whereas only a slight decrease was observed in the ice $p \mathrm{CO}_{2}[$ bulk] at that 

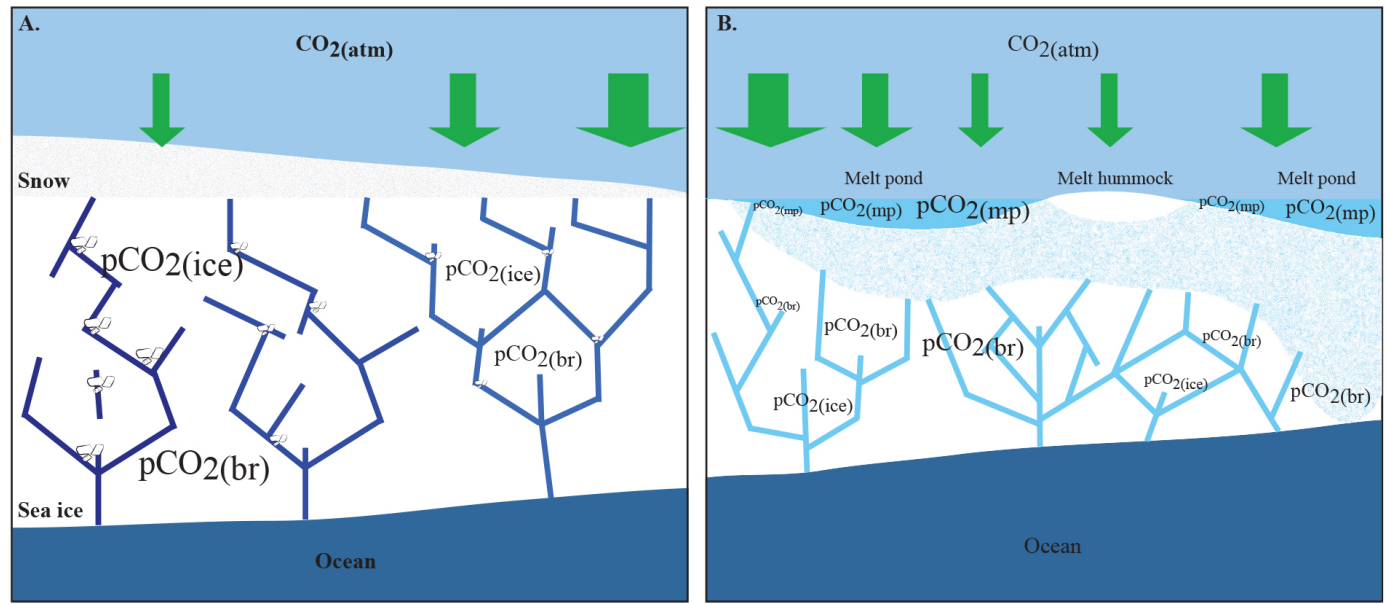

Figure 10. Schematic illustration of the inorganic carbon dynamics of melt-pond-covered first-year sea ice. (a) The increase of the ice temperature and the decrease of the salinity, associated with the dissolution of ikaite crystals, promote the decrease of the bulk ice and brine $p \mathrm{CO}_{2}$. (b) Formation of melt ponds at the surface of the ice and percolation of meltwater into the ice matrix further decreases the $p \mathrm{CO}_{2}$ with episodes of partial recovery, due to surface exchanges with the atmosphere. The $p \mathrm{CO}_{2}$ level is indicated by the size of the writing. The intensity of the $\mathrm{CO}_{2}$ uptake is indicated by the size of the arrow.

point. The percolation of meltwater with low in situ $p \mathrm{CO}_{2}$ initiated a decrease in the brine $p \mathrm{CO}_{2}$ [in situ] to similar concentrations as in the melt ponds. Other examples are observed on 17 June, and then again on 19 and 21 June. On 17 June, high in situ $p \mathrm{CO}_{2}$ meltwater percolation through the ice matrix was associated with an increase in brine $p \mathrm{CO}_{2}$ [in situ] whereas the ice $p \mathrm{CO}_{2}$ [bulk] remained constant. On 19 and 21 June, the brine $p \mathrm{CO}_{2}$ [in situ] decreased to the ice $p \mathrm{CO}_{2}[\mathrm{bulk}]$ value. Therefore, changes in sea ice $p \mathrm{CO}_{2}$ [bulk] are less variable than brine $p \mathrm{CO}_{2}$ [in situ], reflecting mostly internal melting due to temperature and resultant salinity changes in the ice cover. Brine $p \mathrm{CO}_{2}$ [in situ] highlight rapid changes in the brine network such as infiltration of meltwater from melt ponds (Geilfus et al., 2014).

To evaluate if the sackhole technique yielded uncontaminated brine, we compared $\mathrm{TA}_{\mathrm{br}}$ and $\mathrm{TCO}_{2 \mathrm{br}}$ with $\mathrm{TA}$ and $T \mathrm{CO}_{2}$ estimated from $\mathrm{TA}_{\text {ice }}$ and $\mathrm{TCO}_{2 \text { ice }}$ and the calculated brine volume (Fig. 8) (Cox and Weeks, 1983; Leppäranta and Manninen, 1988). Both methods yield similar TA and $T \mathrm{CO}_{2}$ concentrations (from 274 to $3554 \mu \mathrm{mol} \mathrm{kg}^{-1}$ and from 283 to $3189 \mu \mathrm{mol} \mathrm{kg}^{-1}$, respectively), with a similar relationship between TA and $T \mathrm{CO}_{2}$ with $R^{2}$ values of 0.84 and 0.85 , respectively. The scatter between the two methods could be due to the impossibility of determining the exact original depth from which the brine seeped, especially if melt ponds are present at the surface of the ice cover.

As melt ponds developed, freshwater percolation through the ice matrix may form a freshwater layer beneath the sea ice (Hanson, 1965) though an accumulation of under-ice meltwater was not observed during our survey. Perhaps this is because the stage of ice melt was not sufficiently advanced and/or under-ice currents effectively mixed the freshwater layer beneath the ice. The only noticeable impact of the percolation of melt pond water on the underlying seawater was observed on 20 June where the decrease of $\mathrm{TA}_{\mathrm{sw}}$ and $\mathrm{TCO}_{2 \mathrm{sw}}$ was associated with the low isotopic ratio of $\delta^{18} \mathrm{O}$ and $\delta \mathrm{D}$ captured over a very short period (Fig. 6).

As in previous studies, the relationships between $n \mathrm{TA}$ and $n T \mathrm{CO}_{2}$ in seawater, brine and sea ice may determine the main processes affecting the carbonate system. In Fig. 9, the dotted lines represent the response of inorganic carbon and alkalinity to different processes (after Zeebe and WolfGladrow, 2001). An exchange of $\mathrm{CO}_{2 \text { (gas) }}$ will affect $T \mathrm{CO}_{2}$ while TA will remain constant. The precipitation-dissolution of ikaite will affect TA and $T \mathrm{CO}_{2}$ at a ratio of $2: 1$. Biological activity will increase TA slightly and reduce $T \mathrm{CO}_{2}$ slightly in the ratio TA: $T \mathrm{CO}_{2}=-0.16$ (Lazar and Loya, 1991). To calculate these theoretical effects we assumed that seawater sampled at $50 \mathrm{~m}$ (on average: $T=-1.62{ }^{\circ} \mathrm{C} ; S=$ 32.43; $\mathrm{TA}=2229 \mu \mathrm{mol} \mathrm{kg}{ }^{-1}$ and $\mathrm{TCO}_{2}=2135 \mu \mathrm{mol} \mathrm{kg}^{-1}$, Fig. 6) was not influenced by the overlying melting sea ice. Sea ice $n \mathrm{TA}$ and $n \mathrm{TCO}_{2}$ data fall along the ikaite dissolution line while brine and melt pond samples fall between the ikaite dissolution line and the $\mathrm{CO}_{2}$ uptake line, suggesting both processes occurred in combination (Fig. 9). We posit that ikaite crystals formed in winter dissolved during spring, thereby lowering $p \mathrm{CO}_{2}$ and enhancing $\mathrm{CO}_{2}$ uptake. The dissolution of the ikaite crystals increased $n \mathrm{TA}$ and $n \mathrm{TCO}_{2}$ (at a $2: 1$ ratio) in the upper brine layer and melt ponds, while the uptake of $\mathrm{CO}_{2}$ only increased $n T \mathrm{CO}_{2}$. This explains the high $n \mathrm{TA}$ and $n \mathrm{TCO}_{2}$ in Fig. 5. This theory is lent further credibility by ikaite crystals observed in the sea ice. The mean concentration of algal biomass ( $\mathrm{Chl} a$ ) in bulk sea ice decreased from $23.2 \mu \mathrm{gL}^{-1}$ on 4 June to $1.1 \mu \mathrm{gL}^{-1}$ on 12 June, 
and $\mathrm{Chl} a$ concentration in melt ponds ranged from 0.1 to $0.4 \mu \mathrm{gL}^{-1}$ (C. Mundy and V. Galindo, unpublished data). The loss of biomass could result from the warming and melting of the ice (Zeebe et al., 1996; Galindo et al., 2014). These concentrations are in the same range as those reported by Mundy et al. (2011) and Geilfus et al. (2012b) on melting landfast sea ice in the Beaufort Sea. From the brine profiles in Fig. 5 and from the trend of the sea ice samples in Fig. 9, we surmise that brine dilution and calcium carbonate dissolution are the main factors controlling $\mathrm{CO}_{2}$ exchange during our observation period. However, most of the calcium carbonate dissolution trend holds over 4-5 samples located in the top $20 \mathrm{~cm}$ of the sea ice cover. When $n \mathrm{TA}$ and $n T \mathrm{CO}_{2}$ are less than $500 \mu \mathrm{mol} \mathrm{kg}^{-1}$ ( $80 \%$ of the sea ice cover including the bottom $10 \mathrm{~cm}$ layer, rich in $\mathrm{Chl} a$ ), the ice samples pull the trend to the left of the calcium carbonate dissolution line, suggesting an increasing influence of algal $\mathrm{CO}_{2}$ uptake, strong enough to maintain the bottom ice and brine $p \mathrm{CO}_{2}$ at low values close to the nearly saturated water values at the ice-water interface. This biological effect on $\mathrm{TCO}_{2}$ is probably limited to the very bottom decaying section of the sea ice cover (Søgaard et al., 2013; Glud et al., 2014). This is similar to what has been described in the Beaufort Sea (Arctic, Geilfus et al., 2012b) and in the Weddell Sea (Antarctica, Papadimitriou et al., 2012) on landfast sea ice, although during early spring, i.e., at ice temperatures colder than those observed during the present study. Therefore sea ice and brine samples from these other studies are located on the other side of the seawater value, i.e., lying between the precipitation of calcium carbonate and the release of $\mathrm{CO}_{2}$, in the $n \mathrm{TA} / n T \mathrm{CO}_{2}$ space.

The $\mathrm{CO}_{2}$ fluxes reported here are lower than fluxes reported by Semiletov et al. (2004) over melt ponds, but similar to fluxes reported by Geilfus et al. (2012b) over sea ice and melt ponds and similar to fluxes reported by Nomura et al. (2013) on Antarctic and Arctic sea ice during periods of snowmelt and surface flooding. $\mathrm{CO}_{2}$ fluxes over sea ice depend on the ice permeability and the $\mathrm{CO}_{2}$ concentration gradient between the ice surface and the atmosphere conveyed through the liquid phase (i.e., brine and meltwater). Brine and melt ponds were undersaturated with respect to the atmosphere (Fig. 5). The sea ice uptake of atmospheric $\mathrm{CO}_{2}$ was at first moderate $\left(\sim-1 \mathrm{mmolm}^{-2}\right.$ day $^{-1}$, Fig. 7) due to brine being slightly undersaturated. Then the decrease of the brine $p \mathrm{CO}_{2}$ [in situ] due to the percolation of meltwater with low in situ $p \mathrm{CO}_{2}$ intensified the uptake of atmospheric $\mathrm{CO}_{2}$ (up to $-5.4 \mathrm{mmol} \mathrm{m}^{-2} \mathrm{day}^{-1}$ ) by the ice. As the brine $p \mathrm{CO}_{2}$ [in situ] increased, the uptake of $\mathrm{CO}_{2}$ decreased accordingly $\left(\sim-1 \mathrm{mmol} \mathrm{m}^{-2} \mathrm{day}^{-1}\right)$. In addition, insignificant fluxes (in the range of $-0.005 \mathrm{mmol} \mathrm{m}^{-2} \mathrm{day}^{-1}$ ) were detected over interposed ice, similar to Nomura et al. (2010b) and Geilfus et al. (2012b), who reported fluxes $\sim 0 \mathrm{mmol} \mathrm{m}^{-2} \mathrm{day}^{-1}$ on superimposed ice. During the initial formation of melt ponds, the low in situ $p \mathrm{CO}_{2}$ yielded a strong uptake of atmospheric $\mathrm{CO}_{2}\left(-3.8 \mathrm{mmol} \mathrm{m}^{-2}\right.$ day $\left.^{-1}\right)$.
However, as the melt pond $p \mathrm{CO}_{2}$ [in situ $]$ approached equilibrium with the atmosphere, melt pond $\mathrm{CO}_{2}$ uptake decreased and stabilized around $\sim-1 \mathrm{mmol} \mathrm{m}^{-2} \mathrm{day}^{-1}$.

To estimate the total uptake of atmospheric $\mathrm{CO}_{2}$ (Fig. 7) over the sampling area $\left(F_{\text {tot }}\right.$, crosses), we used the pond coverage (fraction $0 \leq x \leq 1$ ) (Fig. 2) to weight the fluxes over sea ice ( $F_{\text {ice }}$, open circles) and over melt ponds $\left(F_{\mathrm{mp}}\right.$, black triangles) respectively, using the following equation:

$F_{\text {tot }}=F_{\text {ice }}(1-x)+F_{\mathrm{mp}} \cdot x$.

The melt pond coverage (Fig. 2) was obtained six times between the date of pond onset (10 June) and the final sampling date with a terrestrial laser scanner. The scanner was used to measure the surface topography of an untouched $80 \mathrm{~m} \times 160 \mathrm{~m}$ area of sea ice and could differentiate between ice cover and melt ponds at the surface, providing the pond fraction (Landy et al., 2014). $F_{\text {tot }}$ peaked during the initial formation of the melt ponds, and then returned to previous values $\left(-1 \mathrm{mmolm}^{-2} \mathrm{day}^{-1}\right)$ when melt ponds were the dominant surface feature. $p \mathrm{CO}_{2}$ conditions in melt ponds are determined by a balance between equilibration with atmospheric $\mathrm{CO}_{2}$ and the continuous supply of low- $p \mathrm{CO}_{2}$ meltwater from melting snow and sea ice. This allows melt ponds to be a continuous but moderate $\mathrm{CO}_{2}$ sink. Considering the mean $F_{\text {tot }}$ after melt pond onset $\left(=-1.15 \mathrm{mmol} \mathrm{m}^{-2}\right.$ day $^{-1}$ ) over $8.4 \times 10^{6} \mathrm{~km}^{2}$ of sea ice (i.e., the difference between the maximum and the minimum annual Arctic sea ice extents; Dieckmann and Hellmer, 2010) over a 90-day duration (the length of the spring and summer melt period), we derive an uptake for this annual melt period of $-10.4 \mathrm{Tg} \mathrm{Cyr}^{-1}$, in addition to existing annual estimates of Arctic oceanic $\mathrm{CO}_{2}$ uptake. However, mixing the melt of the sea ice observed during this study (with average characteristics of $T=-1.1^{\circ} \mathrm{C}, S=$ $3.8, \mathrm{TA}=296 \mu \mathrm{mol} \mathrm{kg}^{-1}$ and $\mathrm{TCO}_{2}=228 \mu \mathrm{mol} \mathrm{kg}^{-1}$ ) in a $20 \mathrm{~m}$ thick mixed layer (with average water column characteristics of $T=-1.62{ }^{\circ} \mathrm{C} ; S=32.4$; TA $=2229 \mu \mathrm{mol} \mathrm{kg}^{-1}$ and $\mathrm{TCO}_{2}=2135 \mu \mathrm{mol} \mathrm{kg}{ }^{-1}$ ) will result in a $9.4 \mu \mathrm{atm} p \mathrm{CO}_{2}$ decrease in the seawater and an oceanic uptake of $0.55 \mathrm{mmol}$ of $\mathrm{CO}_{2} \mathrm{~m}^{-2} \mathrm{day}^{-1}$ over the 90 -day melt period. This corresponds to a total oceanic uptake of $-5 \mathrm{Tg}$ of $\mathrm{C} \mathrm{yr}^{-1}$. These estimations are in the same range as previous work from Rysgaard et al. (2011), who estimated an overall budget for Arctic sea ice between 14 and $31 \mathrm{Tg}$ of $\mathrm{Cyr}^{-1}$, depending on whether the precipitation of calcium carbonate took place in the ice or not. Other estimates of carbon uptake by the Arctic Ocean include Takahashi et al. (2009), who estimated oceanic uptake of $121 \mathrm{Tg}$ of $\mathrm{Cyr}^{-1}$ for an area north of $66^{\circ} \mathrm{N}$ while Bates and Mathis (2009) estimated an uptake between 66 and $199 \mathrm{Tg}$ of $\mathrm{Cyr}^{-1}$ for the Arctic Ocean. However, these studies considered sea ice an impermeable barrier, ignoring the potential role of ice-covered seas on gas exchange between the ocean and the atmosphere. We surmise that melting sea ice may play an important role in mediating the exchange of $\mathrm{CO}_{2}$ between the atmosphere and ocean at high latitudes 
and could provide an additional uptake to previous estimates (Bates and Mathis, 2009; Takahashi et al., 2009).

\section{Conclusions}

We investigated the evolution of inorganic carbon within landfast first-year sea ice in Resolute Passage, Nunavut, from 3 to 23 June 2012 during the spring and summer melt period. Temperature profiles became isothermal $\left(\sim-1^{\circ} \mathrm{C}\right)$ with low salinity at the surface $(\sim 0)$. Melt ponds started to form at the surface of the ice on 10 June.

Early in the melt period, increased ice temperatures and subsequent decreased bulk ice salinity and dissolution of ikaite crystals promoted a strong decrease of TA, $T \mathrm{CO}_{2}$ and $p \mathrm{CO}_{2}$ observed in bulk sea ice and brines (Fig. 10a). The decrease of $p \mathrm{CO}_{2}$ caused sea ice to act as a sink for the atmospheric $\mathrm{CO}_{2}\left(\sim-1 \mathrm{mmol} \mathrm{m}^{-2} \mathrm{day}^{-1}\right)$. This sink increased (up to $-5.4 \mathrm{mmol} \mathrm{m}^{-2} \mathrm{day}^{-1}$ ) during the initial formation of melt ponds due to their very low $p \mathrm{CO}_{2}$ levels. Percolations of melt pond water into the ice matrix increased brine dilution and decreased brine TA, $T \mathrm{CO}_{2}$ and $p \mathrm{CO}_{2}$ (Fig. 10b). Low $\mathrm{TA}_{\mathrm{br}}$ and $\mathrm{TCO}_{2 \mathrm{br}}$ concentrations observed were associated with the percolation of meltwater from melt ponds, and the brine $p \mathrm{CO}_{2}$ [in situ] was controlled by the melt ponds. The melt pond $p \mathrm{CO}_{2}[$ in situ] was low (36 $\mu \mathrm{atm})$ because melt ponds formed from melted snow and surface sea ice melt. The percolation of this low $p \mathrm{CO}_{2}$, low salinity meltwater into the sea ice matrix decreased the brine $p \mathrm{CO}_{2}$ [in situ] to $20 \mu \mathrm{atm}$. As sea ice temperatures rose, meltwater was continuously supplied to the ponds, which prevented melt ponds from fully equilibrating with the atmospheric $\mathrm{CO}_{2}$ concentration. Instead, $p \mathrm{CO}_{2}$ in the melt ponds fluctuated between $0 \mu \mathrm{atm}$ and the atmospheric concentration (395 $\mu \mathrm{atm})$. As melt ponds reached equilibrium with the atmosphere, their uptake became less significant, but because melt ponds are continuously supplied with fresh meltwater while simultaneously draining to the ocean, the melt pond $p \mathrm{CO}_{2}$ [in situ] remained undersaturated and promoted a continuous but moderate uptake of $\mathrm{CO}_{2}$ from the atmosphere $\left(\sim-1 \mathrm{mmol} \mathrm{m}^{-2} \mathrm{day}^{-1}\right)$.

Based on the present study, we estimate an atmospheric $\mathrm{CO}_{2}$ uptake due to the melt of the seasonal sea ice in the Arctic to be on the order of $-10.4 \mathrm{Tg}$ of $\mathrm{C} \mathrm{yr}^{-1}$. This represents an additional uptake of 5-15\% for the Arctic Ocean from previous estimates as reported when sea ice was considered a barrier to these fluxes (Bates and Mathis, 2009; Takahashi et al., 2009).

Acknowledgements. This study was funded by the Canada Excellence Research Chair (CERC, S. Rysgaard), the Natural Sciences and Engineering Research Council (NSERC) of Canada (T. Papakyriakou) and from the Bigsouth Belspo project (J.-L. Tison) no. SD/CA/05A . This work is a contribution to the Arctic Science Partnership (ASP), the ArcticNet Networks of Centres of
Excellence programs, the SCOR BEPSII project and the ARC-cake club. The authors are grateful to the anonymous reviewers whose comments greatly improved the quality of the manuscript.

Edited by: C. Klaas

\section{References}

Bates, N. R. and Mathis, J. T.: The Arctic Ocean marine carbon cycle: evaluation of air-sea $\mathrm{CO}_{2}$ exchanges, ocean acidification impacts and potential feedbacks, Biogeosciences, 6, 2433-2459, doi:10.5194/bg-6-2433-2009, 2009.

Copin Montégut, C.: A new formula for the effect of temperature on the partial pressure of carbon dioxide in seawater, Mar. Chem., 25, 29-37, 1988.

Cox, G. F. N. and Weeks, W. F.: Salinity variations in sea ice, J. Glaciol., 13, 109-120, 1974.

Cox, G. F. N. and Weeks, W. F.: Equations for determining the gas and brine volumes in sea-ice samples, J. Glaciol., 29, 306-316, 1983.

Crabeck, O., Delille, B., Thomas, D., Geilfus, N.-X., Rysgaard, S., and Tison, J.-L.: $\mathrm{CO}_{2}$ and $\mathrm{CH}_{4}$ in sea ice from a subarctic fjord under influence of riverine input, Biogeosciences, 11, 6525-6538, doi:10.5194/bg-11-6525-2014, 2014.

Dickson, A. G. and Millero, F. J.: A comparison of the equilibrium constants for the dissociation of carbonic acid in seawater media, Deep-Sea Res. Pt. I, 34, 1733-1743, 1987.

Dieckmann, G. S. and Hellmer, H. H.: The importance of Sea Ice: An Overview, in: Sea Ice, second edition, edited by: Thomas, D. N. and Dieckmann, G. S., Wiley-Blackwell, Oxford, UK, 122, 2010.

Dieckmann, G. S., Nehrke, G., Uhlig, C., Göttlicher, J., Gerland, S., Granskog, M. A., and Thomas, D. N.: Brief Communication: Ikaite $\left(\mathrm{CaCO}_{3} \cdot 6 \mathrm{H}_{2} \mathrm{O}\right)$ discovered in Arctic sea ice, The Cryosphere, 4, 227-230, doi:10.5194/tc-4-227-2010, 2010.

Eicken, H., Krouse, H. R., Kadko, D., and Perovich, D. K.: Tracer studies of pathways and rates of meltwater transport through Arctic summer sea ice, J. Geophys. Res., 107, 8046, doi:10.1029/2000JC000583, 2002.

Eicken, H., Grenfell, T. C., Perovich, D. K., Richter-Menge, J. A., and Frey, K.: Hydraulic controls of summer Arctic pack ice albedo, J. Geophys. Res., 109, C08007, doi:10.1029/2003JC001989, 2004.

Fetterer, F. and Untersteiner, N.: Observations of melt ponds on Arctic sea ice, J. Geophys. Res., 103, 24821-24835, 1998.

Frankignoulle, M.: Field-measurements of air sea $\mathrm{CO}_{2}$ exchange, Limnol. Oceanogr., 33, 313-322, 1988.

Freitag, J. and Eicken, H.: Meltwater circulation and permeability of Arctic summer sea ice derived from hydrological field experiments, J. Glaciol., 49, 349-358, 2003.

Galindo, V., Levasseur, M., Mundy, C. J., Gosselin, M., Tremblay, J.-É., Scarratt, M., Gratton, Y., Papakiriakou, T., Poulin, M., and Lizotte, M.: Biological and physical processes influencing sea ice, under-ice algae, and dimethylsulfoniopropionate during spring in the Canadian Arctic Archipelago, J. Geophys. Res.Oceans, 119, 3746-3766, 2014. 
Galley, R. J., Else, B. G. T., Howell, S. E. L., Lukovich, J. V., and Barber, D. G.: Landfast sea ice conditions in the Canadian Arctic: 1983-2009, ARCTIC, 65, 133-144, 2012.

Geilfus, N. X., Delille, B., Verbeke, V., and Tison, J. L.: Towards a method for high vertical resolution measurements of the partial pressure of $\mathrm{CO}_{2}$ within bulk sea ice, J. Glaciol., 58, 287-300, 2012a.

Geilfus, N. X., Carnat, G., Papakyriakou, T., Tison, J. L., Else, B., Thomas, H., Shadwick, E., and Delille, B.: Dynamics of $p \mathrm{CO}_{2}$ and related air-ice $\mathrm{CO}_{2}$ fluxes in the Arctic coastal zone (Amundsen Gulf, Beaufort Sea), J. Geophys. Res., 117, C00G10, doi:10.1029/2011JC007118, 2012b.

Geilfus, N. X., Carnat, G., Dieckmann, G. S., Halden, N., Nehrke, G., Papakyriakou, T., Tison, J. L., and Delille, B.: First estimates of the contribution of $\mathrm{CaCO}_{3}$ precipitation to the release of $\mathrm{CO}_{2}$ to the atmosphere during young sea ice growth, J. Geophys. Res., 118, 244-255, doi:10.1029/2012JC007980, 2013a.

Geilfus, N. X., Galley, R. J., Cooper, M., Halden, N., Hare, A., Wang, F., Søgaard, D. H., and Rysgaard, S.: Gypsum crystals observed in experimental and natural sea ice, Geophys. Res. Lett., 40, 6362-6367, doi:10.1002/2013GL058479, 2013b.

Geilfus, N.-X., Tison, J.-L., Ackley, S. F., Galley, R. J., Rysgaard, S., Miller, L. A., and Delille, B.: Sea ice $p \mathrm{CO}_{2}$ dynamics and airice $\mathrm{CO}_{2}$ fluxes during the Sea Ice Mass Balance in the Antarctic (SIMBA) experiment - Bellingshausen Sea, Antarctica, The Cryosphere, 8, 2395-2407, doi:10.5194/tc-8-2395-2014, 2014.

Gleitz, M., Rutgers van der Loeff, M., Thomas, D. N., Dieckmann, G. S., and Millero, F. J.: Comparison of summer and winter inorganic carbon, oxygen and nutrient concentrations in Antarctic sea ice brine, Mar. Chem., 51, 81-91, 1995.

Glud, R. N., Rysgaard, S., Turner, G., McGinnis, D. F., and Leakey, R. J. G.: Biological- and physical-induced oxygen dynamics in melting sea ice of the Fram Strait, Limnol. Oceanogr., 59, 10971111, 2014.

Hansen, J. W., Thamdrup, B., and Jørgensen, B. B.: Anoxic incubation of sediment in gas-tight plastic bags: a method for biogeochemical processes studies, Mar. Ecol.-Prog. Ser., 208, 273-282, 2000.

Hanson, A. M.: Studies of the mass budget of arctic pack-ice floes, J. Glaciol., 5, 701-709, 1965.

Haraldsson, C., Anderson, L. G., Hassellov, M., Hulth, S., and Olsson, K.: Rapid, high-precision potentiometric titration of alkalinity in ocean and sediment pore waters, Deep-Sea Res. Pt. I, 44, 2031-2044, 1997.

Landy, J. C., Ehn, J. K., Shields, M., and Barber, D. G.: Surface melt pond evolution on landfast first-year sea ice in the Canadian Arctic Archipelago, J. Geophys. Res.-Oceans, 119, 3054-3075, doi:10.1002/2013JC009617, 2014.

Lazar, B. and Loya, Y.: Bioerosion of coral reefs - a chemical approach, Limnol. Oceanogr., 36, 377-383, 1991.

Leppäranta, M. and Manninen, T.: The brine and gas content of sea ice with attention to low salinities and high temperatures, Finnish Institute of Marine Research, Helsinki, Finland, Internal Report, 1988, 15 pp., 1988.

Mehrbach, C., Culberson, C. H., Hawley, J. E., and Pytkowicz, R. M.: Measurements of the apparent dissociation constants of carbonic acid in seawater at atmospheric pressure, Limnol. Oceanogr., 18, 897-907, 1973.
Miller, L. A., Carnat, G., Else, B. G. T., Sutherland, N., and Papakyriakou, T. N.: Carbonate system evolution at the Arctic Ocean surface during autumn freeze-up, J. Geophys. Res., 111, C00G04, doi:10.1029/2011JC007143, 2011.

Mundy, C. J., Gosselin, M., Ehn, J. K., Belzile, C., Poulin, M., Alou, E., Roy, S., Hop, H., Lessard, S., Papakyriakou, T. N., Barber, D. G., and Stewart, J.: Characteristics of two distinct high-light acclimated algal communities during advanced stages of sea ice melt, Polar Biol., 34, 1869-1886, 2011.

Nomura, D., Eicken, H., Gradinger, R., and Shirasawa, K.: Rapid physically driven inversion of the air-sea ice $\mathrm{CO}_{2}$ flux in the seasonal landfast ice off Barrow, Alaska after onset surface melt, Cont. Shelf. Res., 30, 1998-2004, 2010a.

Nomura, D., Yoshikawa-Inoue, H., Toyota, T., and Shirasawa, K.: Effects of snow, snow-melting and re-freezing processes on airsea ice $\mathrm{CO}_{2}$ flux, J. Glaciol., 56, 262-270, $2010 \mathrm{~b}$.

Nomura, D., Granskog, M. A., Assmy, P., Simizu, D., and Hashida, G.: Arctic and Antarctic sea ice acts as a sink for atmospheric $\mathrm{CO}_{2}$ during periods of snowmelt and surface flooding, J. Geophys. Res.-Oceans, 118, 6511-6524, doi:10.1002/2013JC009048, 2013.

Papadimitriou, S., Kennedy, H., Norman, L., Kennedy, D. P., Dieckmann, G. S., and Thomas, D. N.: The effect of biological activity, $\mathrm{CaCO}_{3}$ mineral dynamics, and $\mathrm{CO}_{2}$ degassing in the inorganic carbon cycle in sea ice and late winter-early spring in the Weddell Sea, Antarctica, J. Geophys. Res., 117, C08011, doi:10.1029/2012JC008058, 2012.

Papakyriakou, T. and Miller, L.: Springtime $\mathrm{CO}_{2}$ exchange over seasonal sea ice in the Canadian Arctic Archipelago, Ann. Glaciol., 52, 215-224, doi:10.3189/172756411795931534, 2011.

Parmentier, F.-J. W., Christensen, T. R., Sørensen, L. L., Rysgaard, S., McGuire, A. D., Miller, P. A., and Walker, D. A.: The impact of lower sea-ice extent on Arctic greenhouse-gas exchange, Nature Climate Change, 3, 195-202, doi:10.1038/NCLIMATE1784, 2013.

Perovich, D. K., Tucker, W. B., and Ligett, K. A.: Aerial observations of the evolution of ice surface conditions during summer, $\mathrm{J}$ Geophys. Res., 107, 8048, doi:10.1029/2000JC000449, 2002.

Perovich, D. K., Jones, K. F., Light, B., Eicken, H., Markus, T., Stroeve, J., and Lindsay, R.: Solar partitioning in a changing Arctic sea-ice cover, Ann. Glaciol., 52, 192-196, 2011.

Polashenski, C., Perovich, D., and Courville, Z.: The mechanisms of sea ice melt pond formation and evolution, J. Geophys. Res., 117, C01001, doi:10.1029/2011JC007231, 2012.

Rösel, A. and Kaleschke, L.: Exceptional melt pond occurrence in the years 2007 and 2011 on the Arctic sea ice revealed from MODIS satellite data, J. Geophys. Res., 117, C05018, doi:10.1029/2011JC007869, 2012.

Rysgaard, S., Glud, R. N., Sejr, M. K., Bendtsen, J., and Christensen, P. B.: Inorganic carbon transport during sea ice growth and decay: a carbon pump in polar seas, J. Geophys. Res., 112, C03016, doi:10.1029/2006JC003572, 2007.

Rysgaard, S., Bendtsen, J., Delille, B., Dieckmann, G. S., Glud, R. N., Kennedy, H., Mortensen, J., Papadimitriou, S., Thomas, D. N., and Tison, J. L.: Sea ice contribution to the air-sea $\mathrm{CO}_{2}$ exchange in the Arctic and Southern Oceans, Tellus B, 63, 823830, 2011. 
Rysgaard, S., Glud, R. N., Lennert, K., Cooper, M., Halden, N., Leakey, R. J. G., Hawthorne, F. C., and Barber, D.: Ikaite crystals in melting sea ice - implications for $p \mathrm{CO}_{2}$ and $\mathrm{pH}$ levels in Arctic surface waters, The Cryosphere, 6, 901-908, doi:10.5194/tc6-901-2012, 2012a.

Rysgaard, S., Mortensen, J., Juul-Pedersen, T., Sørensen, L. L., Lennert, K., Søgaard, D. H., Arendt, K. E., Blicher, M. E., Sejr, M. K., and Bendtsen, J.: High air-sea $\mathrm{CO}_{2}$ uptake rates in nearshore and shelf areas of Southern Greenland: temporal and spatial variability, Mar. Chem., 128-129, 26-33, 2012b.

Rysgaard, S., Søgaard, D. H., Cooper, M., Pućko, M., Lennert, K., Papakyriakou, T. N., Wang, F., Geilfus, N. X., Glud, R. N., Ehn, J., McGinnis, D. F., Attard, K., Sievers, J., Deming, J. W., and Barber, D.: Ikaite crystal distribution in winter sea ice and implications for $\mathrm{CO}_{2}$ system dynamics, The Cryosphere, 7, 707-718, doi:10.5194/tc-7-707-2013, 2013.

Rysgaard, S., Wang, F., Galley, R. J., Grimm, R., Notz, D., Lemes, M., Geilfus, N.-X., Chaulk, A., Hare, A. A., Crabeck, O., Else, B. G. T., Campbell, K., Sørensen, L. L., Sievers, J., and Papakyriakou, T.: Temporal dynamics of ikaite in experimental sea ice, The Cryosphere, 8, 1469-1478, doi:10.5194/tc-8-14692014, 2014.

Semiletov, I. P., Makshtas, A., Akasofu, S. I., and Andreas, E. L.: Atmospheric $\mathrm{CO}_{2}$ balance: the role of Arctic sea ice, Geophys. Res. Lett., 31, L05121, doi:10.1029/2003GL017996, 2004.

Søgaard, D. H., Thomas, D. N., Rysgaard, S., Norman, L., Kaartokallio, H., Juul-Pedersen, T., Glud, R. N., and Geilfus, N. X.: The relative contributions of biological and abiotic processes to the carbon dynamics in subarctic sea ice, Polar Biol., 36, 17611777, doi:10.1007/s00300-013-1396-3, 2013.
Takahashi, T., Sutherland, S. C., Wanninkhof, R., Sweeney, C., Feely, R. A., Chipman, D. W., Hales, B., Friederich, G., Chavez, F., Sabine, C., Watson, A., Bakker, D. C. E., Schuster, U., Metzl, N., Inoue, H. Y., Ishii, M., Midorikawa, T., Nojiri, Y., Kortzinger, A., Steinhoff, T., Hoppenma, M., Olafsson, J., Arnarson, T. S., Tilbrook, B., Johannessen, T., Olsen, A., Bellerby, R., Wong, C. S., Delille, B., Bates, N. R., and de Baar, H. J. W.: Climatological mean and decadal change in surface ocean $p \mathrm{CO}_{2}$, and net sea-air $\mathrm{CO}_{2}$ flux over the global oceans, Deep-Sea Res. Pt. II, 56, 554-577, 2009.

Taylor, P. D. and Feltham, D. L.: A model of melt pond evolution on sea ice, J. Geophys. Res., 109, C12007, doi:10.1029/2004JC002361, 2004.

Untersteiner, N.: Natural desalination and equilibrium salinity profile of perennial sea ice, J. Geophys. Res., 73, 1251-1257, 1968.

Weeks, W. F. (Ed.): On Sea Ice, Fairbanks, Alaska, 664 pp., 2010.

Zeebe, R. E. and Wolf-Gladrow, D.: $\mathrm{CO}_{2}$ in Seawater: Equilibrium, Kinetics, Isotopes, Elsevier, 2001.

Zeebe, R. E., Eicken, H., Robinson, D. H., WolfGladrow, D., and Dieckmann, G. S.: Modeling the heating and melting of sea ice through light absorption by microalgae, J. Geophys. Res., 101, 1163-1181, 1996.

Zhou, J. Y., Delille, B., Eicken, H., Vancoppenolle, M., Brabant, F., Carnat, G., Geilfus, N. X., Papakyriakou, T., Heinesch, B., and Tison, J. L.: Physical and biogeochemical properties in landfast sea ice (Barrow, Alaska): insights on brine and gas dynamics across seasons, J. Geophys. Res.-Oceans, 118, 3172-3189, 2013. 